\title{
Developmental Exposure to Di-(2-ethylhexyl) Phthalate Induces Cerebellar Granule Cell Apoptosis via the PI3K/AKT Signaling Pathway
}

\author{
Yuanyuan $\mathrm{Fu}^{\dagger}$, Jing Dong ${ }^{\dagger}$, Jianan Wang, Mingdan You, Lingling Wei, \\ Hui Fu, Yuan Wang and Jie Chen* \\ Department of Occupational and Environmental Health, School of Public Health, China Medical University, \\ Shenyang 110122, China
}

Di-(2-ethylhexyl) phthalate (DEHP) is an ubiquitous environmental contaminant because of its extensive use in plastics and its persistence. As an environmental endocrine disruptor, it is suspected to interfere with neurodevelopment in people. However, evidence of the effects of maternal DEHP exposure on cerebellar development in offspring is scarce. The objective of this study was to investigate maternal exposure to DEHP and its effect on apoptosis of cerebellar granule cells (CGCs) and related mechanisms. Pregnant Wistar rats were administrated DEHP $(0,30,300$ and $750 \mathrm{mg} / \mathrm{kg} / \mathrm{d})$ by gavage from gestational day (GD) 0 to postnatal day (PN) 21. Primary CGCs were also exposed to mono-(2-ethylhexyl) phthalate (MEHP), the main metabolite of DEHP, for $24 \mathrm{~h}$ with concentrations of $0,25,100$ and $250 \mu \mathrm{M}$. The CGCs of male offspring from 300 and $750 \mathrm{mg} / \mathrm{kg} / \mathrm{d}$ DEHP exposure groups showed significantly increased apoptosis. In addition, the PI3K/AKT signaling pathway was inhibited in the male offspring of the $300 \mathrm{and} 750 \mathrm{mg} /$ $\mathrm{kg} / \mathrm{d}$ DEHP exposure groups. However, effects on female pups were not obvious. Apoptosis was also elevated and the PI3K/AKT signaling pathway was inhibited after primary CGCs were exposed to MEHP. Furthermore, apoptosis was reduced after treatment with the PI3K/AKT signaling pathway activator, insulin-like growth factor (IGF) 1, and increased after treatment with LY294002, an inhibitor of the PI3K/AKT signaling pathway. These results suggested that maternal DEHP exposure induced apoptosis in the CGCs of male pups via the PI3K/AKT signaling pathway, and the apoptosis could be rescued by IGF1 and aggravated by LY294002.

Key words: DEHP, Cerebellar granule cell, Apoptosis, PI3K/AKT signaling pathway

\section{INTRODUCTION}

Di (2-ethylhexyl) phthalate (DEHP) is a kind of endocrine dis-

Received September 25, 2018, Revised December 11,2018,

Accepted December 12, 2018

* To whom correspondence should be addressed.

TEL: 86-24-31939406, FAX: 86-24-31939406

e-mail: jchen@cmu.edu.cn

"These authors are contributed equally to this work. rupting compound that is often added to polyvinyl chloride materials to increase plasticity [1]. It is widely used in food packaging materials, building decoration materials, children's toys and medical equipment, as well as other products [2-4]. DEHP and plastic substrates combine with non-covalent bonds. Therefore, DEHP constantly escapes from plastic products to pollute the atmosphere, soil and water, and ultimately have adverse impacts on human health $[5,6]$. Humans are exposed to DEHP through various ways predominantly through food intake, but also by drinking water, skin absorption and intravenous injection $[7,8]$. After DEHP
Copyright $\odot$ Experimental Neurobiology 2018. www.enjournal.org
This is an Open Access article distributed under the terms of the Creative Commons Attribution Non-Commercial License (http://creativecommons.org/licenses/by-nc/4.0) which permits unrestricted non-commercial use, distribution, and reproduction in any medium, provided the original work is properly cited. 
enters the body, it can rapidly metabolize to mono-(2-ethylhexyl) phthalate (MEHP), its primary metabolite, in the gastrointestinal tract and other tissues $[9,10]$. MEHP is believed to be the main way in DEHP exerts toxic effects since it is 10 times more toxic than its parent compound [11].

It has been thought that women, especially pregnant women, are more susceptible to DEHP than men in the same living environment [12]. Moreover, it was deemed that DEHP and MEHP could pass through the placental barrier and the imperfect fetal cerebral blood barrier to affect fetal development [13-15]. Studies have shown that maternal exposure to DEHP exerted deleterious effects on fetal immune, cardiovascular and endocrine system development [16-19]. Lately, there has been increasing concern regarding maternal DEHP exposure on fetal neural development. However, most of these studies have focused on epidemiological investigations.

In neural development, the normal function of cerebellum plays an important role [20,21]. It is widely considered that altered cerebellar structure and function are associated with emotional, cognitive and social behavior abnormalities $[22,23]$. Proliferation, differentiation and apoptosis are pivotal steps during early postnatal cerebellar development, and disturbances in any of these may lead to changes in cerebellar function and structure [24-26]. It is generally believed that the process of apoptosis is strictly regulated by the organism to maintain the stability of various tissues and organs [27]. However, excessive cell proliferation and apoptosis can ensue when the regulation of apoptosis is unbalanced, which leads to the occurrence of related diseases such as Alzheimer's disease, brain injury and several chronic neurodegenerative disease [2831]. Accumulating evidence suggests that the PI3K/AKT signaling pathway is closely related to neuronal apoptosis $[32,33]$. The $\mathrm{PI} 3 \mathrm{~K} / \mathrm{AKT}$ signaling pathway exists in all mammalian cells and is regulated by a series of extracellular signals such as growth factors and cytokines [34]. It regulates cell survival by phosphorylating a series of downstream targets such as Bcl-2 family members and the caspase family of proteins. Bcl-2 is an important downstream effector of the PI3K/AKT signaling pathway, which is negatively related to regulation of apoptosis $[35,36]$. When PI3K-dependent AKT is activated, $\mathrm{Bcl}-2$ depolymerizes with phosphorylated $\mathrm{Bad}$ and free $\mathrm{Bcl}-2$ can play an anti-apoptotic role. Bax also belongs to the Bcl2 family and acts as a pro-apoptotic factor $[37,38]$. As an activator of the PI3K/AKT signaling pathway, insulin like growth factor-1 (IGF1) can reduce apoptosis induced by the inhibition of the PI3K/AKT signaling pathway [39], while a chemical inhibitor, LY294002, can inhibit the PI3K/AKT signaling pathway.

Although numerous studies on DEHP neurotoxicity have been conducted [15, 40-46], relatively little research has been done on its effect on the cerebellum, notably, toxicities and related mechanisms are still unclear. Therefore, the aim of the present study was to investigate the effects of DEHP on apoptosis in cerebellar granule cells (CGCs) and the underlying mechanisms involved.

\section{MATERIALS AND METHODS}

\section{Animals}

Female Wistar rats (230 250 g) were obtained from the Center for Experimental Animals at China Medical University (Shenyang, China) with a National Animal Use License number of SCXKLN2013-0007. All experiments and surgical procedures were approved by the Animal Use and Care Committee at China Medical University, which complies with the National Institutes of Health Guide for the Care and Use of Laboratory Animals. All efforts were made to minimize the number of animals used and their suffering. Rats were housed at a temperature of $24 \pm 1^{\circ} \mathrm{C}$ with $12 \mathrm{~h}$ light/12 $\mathrm{h}$ dark cycles. DEHP-free food and water were provided ad libitum.

\section{DEHP administration}

Female Wistar rats were randomly assigned to four groups ( $\mathrm{n}=10$ per group): the control (only corn oil was administered) and three DEHP treatment groups. Female rats were fed for 1 week and then mated with normal male rats $(\phi / \hat{\delta}=2: 1)$. The day of the vaginal plug was taken as gestational day (GD) 0 . Then pregnant rats were administered, via oral gavage, $0,30 \mathrm{mg} / \mathrm{kg} / \mathrm{d}, 300 \mathrm{mg} / \mathrm{kg} / \mathrm{d}$ and 750 $\mathrm{mg} / \mathrm{kg} / \mathrm{d}$ of DEHP (Sigma-Aldrich, St Louis, MO, USA) in $0.1 \mathrm{ml}$ corn oil (Sigma-Aldrich)/20 g body weight from GD 0 to postnatal day $(\mathrm{PN}) 21$. This dose range was selected with reference to the effects on neurodevelopment measured in previous studies [41, 47].

\section{Primary CGC isolation and treatment}

Primary cultures of CGCs were prepared from 7-day-old Wistar rats and cultured as previously described using a modified method $[48,49]$. In brief, the cerebellum was dissected and kept in Hank's Buffered Salt Solution after the meninges were carefully removed. Then the cerebella were sliced and tissue was dissociated by $0.125 \%$ trypsin solution (Invitrogen, Carlsbad, CA, USA) for $15 \mathrm{~min}$ at $37^{\circ} \mathrm{C}$, and triturated in the presence of DNase I (Genview Scientific, Tallahassee, Florida, USA) and a few drops of fetal bovine serum (Cellmax, Beijing, China). Dissociated cells were collected by centrifugation and resuspended in basal Dulbeccoss Modified Eagle Medium supplemented with 10\% fetal bovine serum and penicillin-streptomycin (Invitrogen). The cell suspension was plated on poly-l-lysine-coated petri dishes and cultured in a $\mathrm{CO}_{2}$ 
incubator. The medium was changed to neuronal culture medium consisting of neurobasal A (Thermo Fisher, Waltham, MA, USA), B27 (Thermo Fisher), glutamine (Sigma-Aldrich) and penicillinstreptomycin after $18 \mathrm{~h}$ of culture. Meanwhile, cytarabine (MedChemExpress, Monmouth Junction, NJ, USA) was added to inhibit the growth of non-neuronal cells. The culture medium was changed every two days.

After 7 days of cell culture, the culture medium was switched to that containing the indicated concentration of MEHP (AccuStandard, New Haven, CT, USA) MEHP was dissolved in dimethyl sulfoxide (DMSO) because of its poor water-solubility to a final concentration of $0.05 \%$, which has no effect on cell development. The medium from the control group contained the same content of DMSO. IGF1 (R\&D Systems, Minneapolis, MN, USA) and LY294002 (MedChemExpress) were added for the indicated periods.

\section{Cell viability assay}

The cell viability assay was performed with a Cell Counting Kit8 (CCK-8; MedChemExpress) according to the manufacturer's instructions. Briefly, cells were seeded in 96-well plates and treated with different concentrations of MEHP, CCK-8 solutions were then added and incubated for $4 \mathrm{~h}$. Absorption at $450 \mathrm{~nm}$ was subsequently measured on a Varioskan Flash (Thermo Fisher). Each experiment was repeated three times. Results were expressed as a percentage of the control that was set as 1 .

\section{Terminal deoxynucleotidyl transferase-mediated dUTP nick-and labeling (TUNEL) assay}

Terminal deoxynucleotidyl transferase-mediated dUTP nickand labeling (TUNEL) assay was performed on cerebellum paraffin-embedded tissue sections and primary CGCs using an in situ cell death detection kit (Roche Diagnostics, Mannheim, Germany) according to the manufacturer's instructions. Briefly, cell smears were washed using phosphate buffered saline (PBS) and fixed with $4 \%$ paraformaldehyde solution for $25 \mathrm{~min}$. Cells were then washed with PBS again and permeabilized using $0.2 \%$ Triton X-100 (Sigma-Aldrich). Tissue sections were heated at $60^{\circ} \mathrm{C}$ for $2 \mathrm{~h}$, followed by washing in xylene and rehydration through a graded series of ethanols and double-distilled water. Sections were then incubated with $20 \mu \mathrm{g} / \mathrm{ml}$ proteinase $\mathrm{K}$ working solution (Beyotime, Shanghai, China) for $30 \mathrm{~min}$ at $37^{\circ} \mathrm{C}$. Finally, cell smears and paraffin sections were labeled by TUNEL reaction mixture, and incubated at $37^{\circ} \mathrm{C}$ in a humidified dark chamber for $1 \mathrm{~h}$. Images were obtained using a fluorescence microscope (Olympus, Tokyo, Japan) under the same conditions of light illumination and at a magnification of $\times 200$ (objective $\times 20$ and ocular $\times 10$ ). TUNEL- positive cells were counted in a blinded manner only if structures were identified clearly. Three different fields were selected from inner granule layer regions per section, respectively, and three sections per animal were evaluated to obtain a mean value. Six male and six female rats per group were used to obtain an overall mean value for subsequent statistical analysis.

\section{Immunofluorescence}

Primary CGCs were fixed and permeabilized as previously described, and then blocked with goat serum (ZhongShan Biotechnology, Beijing, China) for $30 \mathrm{~min}$ at room temperature. Cells were then incubated with mouse monoclonal anti- $\beta$-IIItubulin (1:400; Abcam, Cambridge, MA, USA) and rabbit anti-cleaved caspase 3 (1:100, Cell Signaling Technology, Danvers, MA, USA) overnight at $4^{\circ} \mathrm{C}$. Next day, after washing in PBS three times, a secondary antibody conjugated to the fluorescent markers TRITC or FITC (1:100, Zhong Shan Biotechnology) was added for $2 \mathrm{~h}$. Images were obtained by fluorescence microscopy (Olympus, Japan) at a magnification of $200 \times($ objective $20 \times$ and ocular $10 \times$ ).

\section{Western blotting}

Proteins of pups' cerebella at PN 7, and PN 14 from each group were prepared as previously described. Cells were lysed using a total protein extraction kit (Invent Biotechnologies, Plymouth, MN, USA) for animal tissue and cultured cells according to the manufacturer's instructions. The concentration of protein in tissue lysates was estimated by a Pierce BCA protein assay kit (Thermo Fisher) and diluted to $3 \mu \mathrm{g} / \mu \mathrm{l}$. Samples were then separated on $10 \%$ SDS-acrylamide gels. Proteins were separated by applying a constant voltage of $100 \mathrm{~V}$ for $1.5 \mathrm{~h}$ and then transferred onto polyvinylidene difluoride membranes at a constant voltage of 100 $\mathrm{V}$ for $60 \mathrm{~min}$. After blocking nonspecific sites with Tris-buffered saline (TBS) containing $0.1 \%$ Tween 20 and 5\% defatted dried milk, membranes were washed and incubated with rabbit antip-AKT (1:1000; Cell Signaling Technology), rabbit anti-AKT (1:1000; Cell Signaling Technology), rabbit anti-PI3K (1:1000; Cell Signaling Technology), rabbit anti-Bax (1:1000; Cell Signaling Technology), rabbit anti-cleaved caspase 3 (1:1000; Cell Signaling Technology), mouse- anti-Bcl 2 (0.2 $\mu \mathrm{g} / \mathrm{ml}$; R\&D Systems), rabbit anti-caspase-3 (1:1000; Cell Signaling Technology) and rabbit anti- $\beta$-actin (1:1000; Cell Signaling Technology) overnight at $4^{\circ} \mathrm{C}$. Membranes were then incubated with goat anti-rabbit or mouse anti-goat horseradish peroxidase-conjugated secondary antibody (1:2500; ZhongShan Biotechnology). Finally, blots were visualized using the Bioanalytical Imaging System (Azure Biosystems, Dublin, CA, USA). The relative density of each blot was quantified via Image-Pro Plus 6.0 software (Media Cybernetics, Rockville, MD, 
USA).

\section{Statistics}

All analyses were carried out by SPSS software, version 21.0 (SPSS Inc., Chicago, IL, USA), and all experiments were performed at least in triplicate. Data on the net optical density of bands was presented as the means \pm standard deviations (SD), and a one-way analysis of variance followed by the Bonferroni test was used to compare the treated groups with the control group. Several independent sample nonparametric tests were used to compare the different groups, and the Kruskal-Wallis test was used to compare treated and control groups. A p value of $<0.05$ was considered statistically significant.

PN 7

PN 14

A

Male

Female

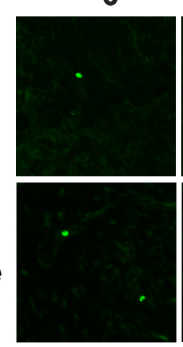

30
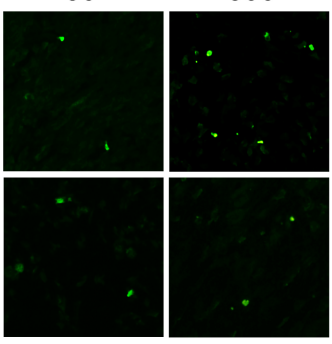

C

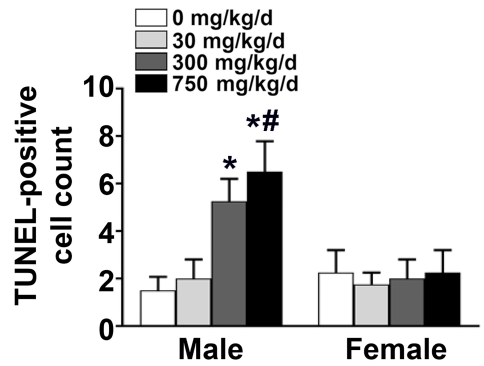

$750 \mathrm{mg} / \mathrm{kg} / \mathrm{d} \mathrm{B}$

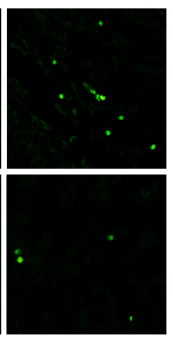

Female

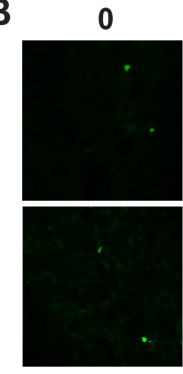

D $\square=\square \mathrm{mg} / \mathrm{kg} / \mathrm{d}$

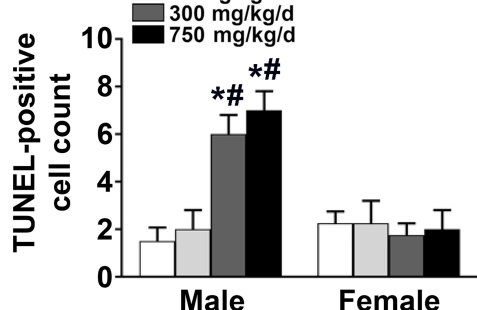

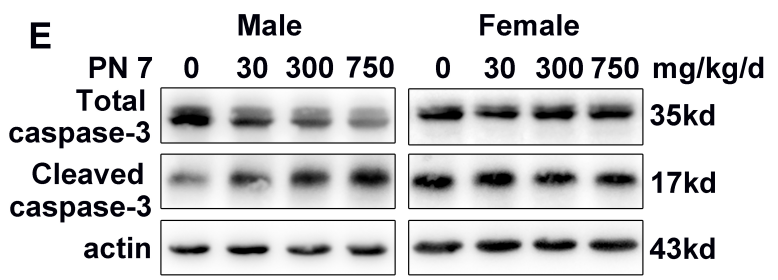

H

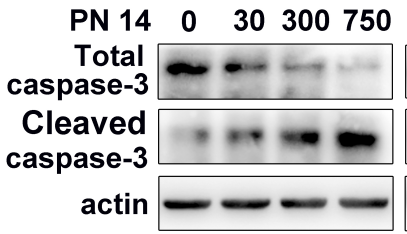

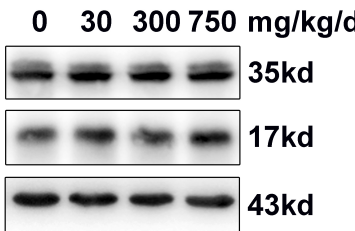
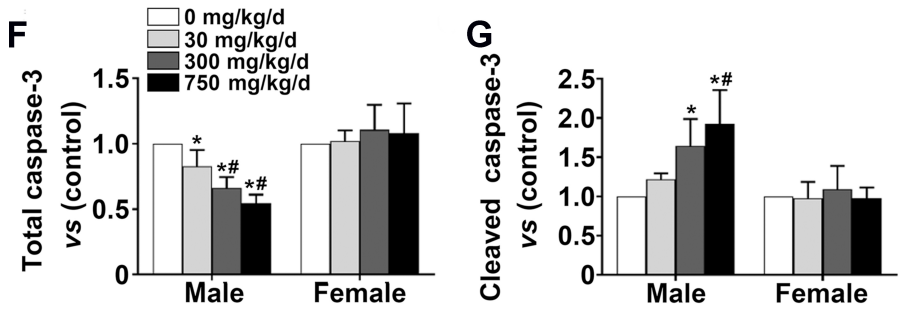

I
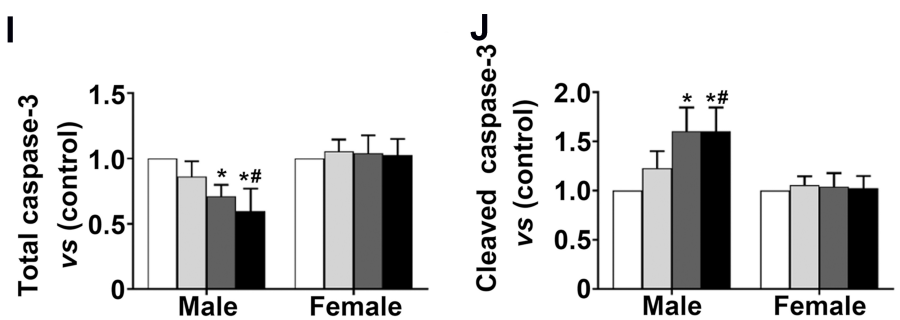

Fig. 1. Effect of maternal DEHP exposure on cerebellar granule cell apoptosis in pups. Representative photomicrographs show fluorescence staining of terminal deoxynucleotidyl transferase-mediated dUTP nick-and labeling (TUNEL)-positive cells in the internal granular layer of cerebellum in the four groups $(0,30,300$ and $750 \mathrm{mg} / \mathrm{kg} / \mathrm{d}$ ). (A) Postnatal (PN) day 7 for males and females, (B) PN 14 for males and females. Corresponding bar graph shows the TUNEL-positive cell count in the four groups.at PN 7 (C) and PN 14 (D). Scale bar=25 $\mu \mathrm{m}$. The scale bar is the same for all images in the figure. Western blots bands represent the expression of cleaved caspase- 3 and caspase 3 for male and female offspring at PN 7 (E) and PN 14 (H). Semiquantitative measurements of cleaved caspase- 3 and total caspase 3 for male and female offspring at PN 7 (F) (G) and PN 14 (I) (J). With each time point, ${ }^{*} \mathrm{p}<0.05$ vs control, ${ }^{*} \mathrm{p}<0.05 \mathrm{vs} 30 \mathrm{mg} / \mathrm{kg} / \mathrm{d}$ contamination group $(\mathrm{n}=6)$. 


\section{RESULTS}

\section{Effects of maternal DEHP exposure on cerebellar granule} cell apoptosis in pups

The TUNEL assay is a widely used for evaluating the apoptosis of cells [50], and caspase-3 is a key executor of apoptosis [51]. To determine whether DEHP exposure played a role in apoptosis, TUNEL assay was performed on cerebellum sections at PN 7 and PN 14. TUNEL positive cells in male pups from the 300 and $750 \mathrm{mg} / \mathrm{kg} / \mathrm{d}$ exposure groups were significantly increased when compared with those of the control group at PN 7 (Fig. 1C. Male: $\mathrm{p}<0.05$ ) and PN 14 (Fig. 1D. Male: $\mathrm{p}<0.05$ ). However, for female offspring, significant changes were not observed at PN 7 and PN 14 (Fig. 1C, Female; Fig. 1D, Female). Consistent with these results, the expression of cleaved caspase- 3 in male pups' of the $300 \mathrm{mg} /$ $\mathrm{kg} / \mathrm{d}$ and $750 \mathrm{mg} / \mathrm{kg} / \mathrm{d}$ exposure groups was significantly also increased when compared with the control at PN 7 (Fig. 1G. Male: $\mathrm{p}<0.05$ ) and PN 14 (Fig. 1J. Male: $\mathrm{p}<0.05$ ), while the level of total caspase-3 was decreased at PN 7 (Fig. 1F. Male: $\mathrm{p}<0.05$ ) and PN 14 (Fig. 1I. Male: $\mathrm{p}<0.05$ ). Moreover, marked differences among the four groups of female offspring were not noted (Fig. 1F, Female; Fig. 1G, Female; Fig. 1I, Female; Fig. 1J, Female). These findings, therefore, suggested that maternal DEHP exposure induced CGC apoptosis in male rat offspring only.

\section{Effects of maternal DEHP exposure on the PI3K/AKT sig- naling pathway}

The $\mathrm{PI} 3 \mathrm{~K} / \mathrm{AKT} / \mathrm{Bcl}-2 / \mathrm{Bax}$ signaling pathway plays an important role in maintaining cell survival and function to regulate physiological processes such as cell apoptosis, division and differentiation $[52,53]$. In this investigation, for male pups, it was found that the expression of p-PI3K (Fig. 2B, Male: $\mathrm{p}<0.05$; Fig. 3B, Male: p $<0.05$ ), p-AKT (Fig. 2D, Male: $p<0.05$; Fig. 3D, Male: $p<0.05$ ) and Bcl-2 (Fig. 2F, Male: $<<0.05$; Fig. 3F, Male: $p<0.05$ ) was significantly decreased in 300 and $750 \mathrm{mg} / \mathrm{kg} / \mathrm{d}$ exposure groups at PN 7 and PN 14 in comparison with the control, and the protein expression
A
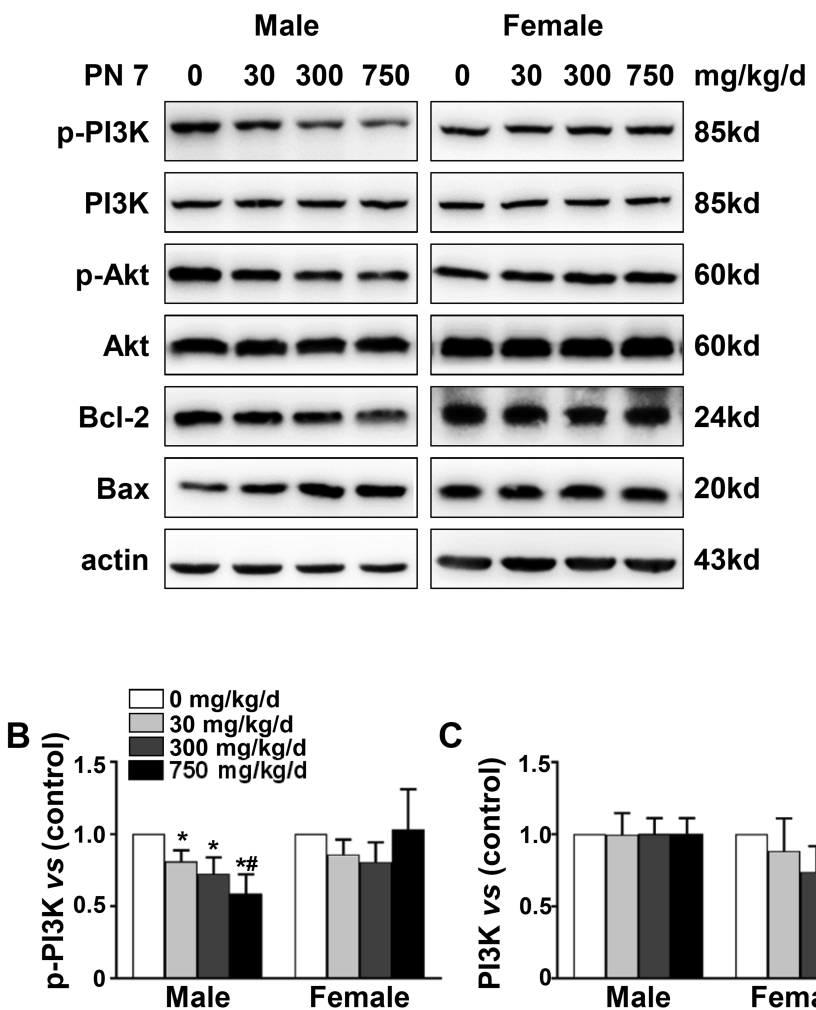

D

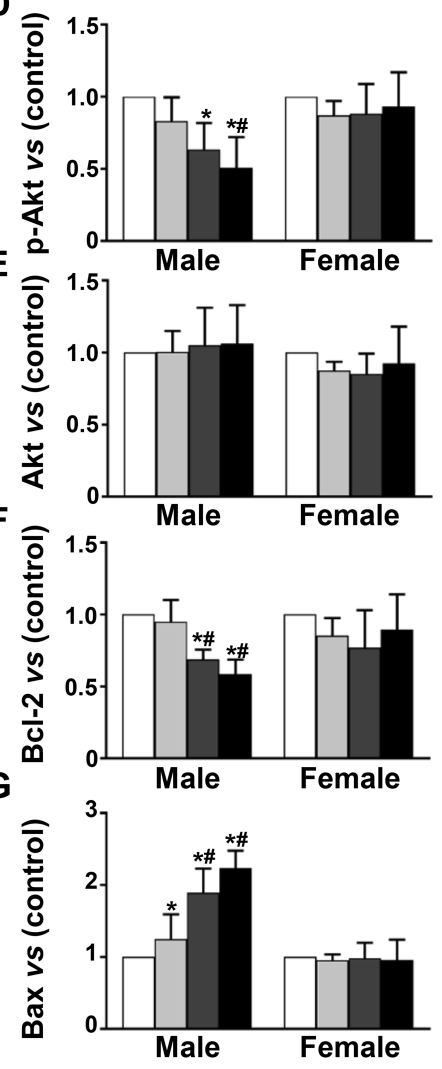

Fig. 2. Effect of maternal DEHP exposure on PI3K/AKT signaling pathway of pups at PN 7. (A) Western blot bands represent the expression level of proteins in the $\mathrm{PI} 3 \mathrm{~K} / \mathrm{AKT} / \mathrm{Bcl}-2 / \mathrm{Bax}$ pathway at PN 7 for males and females. The bar graphs show the results of the semi-quantitative measurement of p-PI3K (B), PI3K (C), p-AKT (D), AKT (E), Bcl-2 (F) and Bax (G). Each bar represents mean \pm standard deviation (SD). The mean expression in offspring from $0,30,300$, and $750 \mathrm{mg} / \mathrm{kg} / \mathrm{d}$ exposure groups is shown as a fold-change compared to the mean expression in the $0 \mathrm{mg} / \mathrm{kg} / \mathrm{d} \mathrm{group} \mathrm{which} \mathrm{was}$ ascribed an arbitrary value of 1 . With each time point, ${ }^{*} \mathrm{p}<0.05 \mathrm{vs}$ control, ${ }^{*} \mathrm{p}<0.05 \mathrm{vs} 30 \mathrm{mg} / \mathrm{kg} / \mathrm{d}$ contamination group ( $\left.\mathrm{n}=6\right)$. 
A
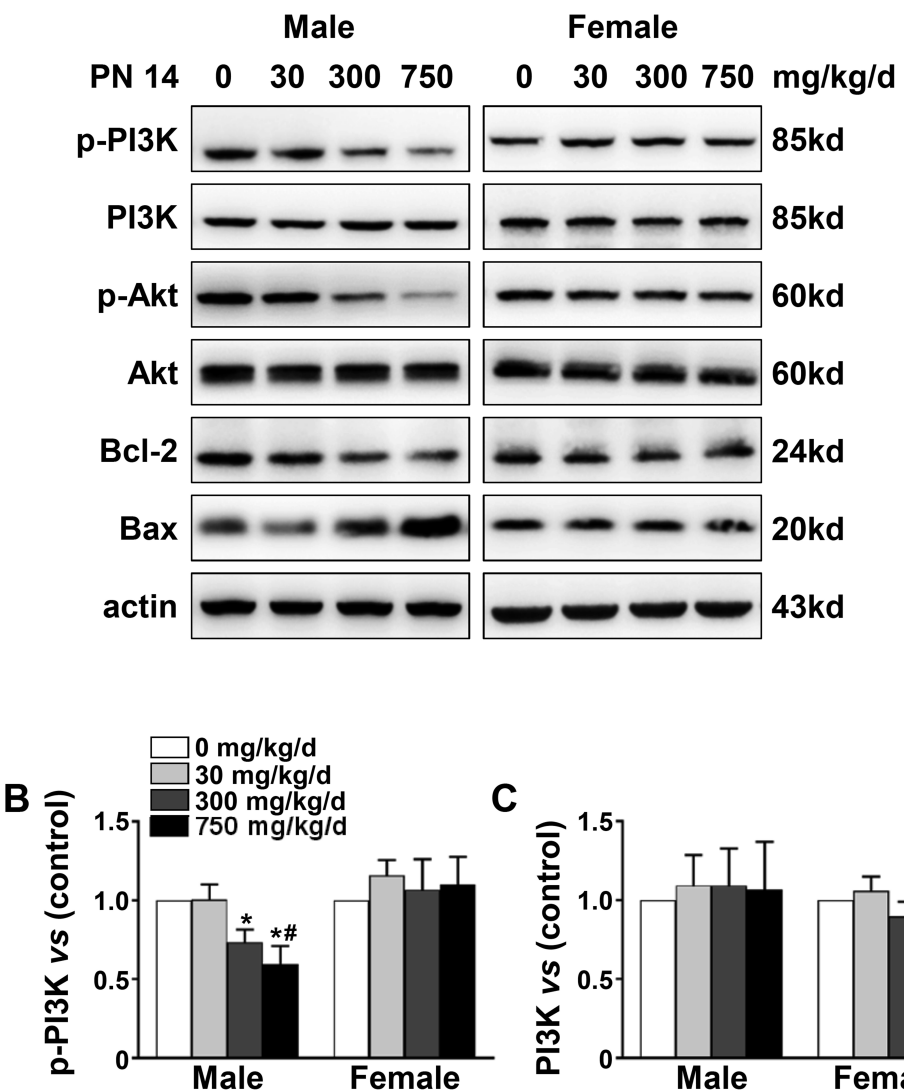

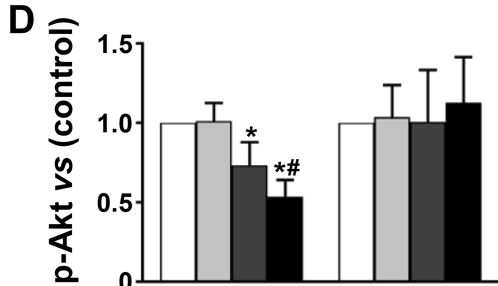

E
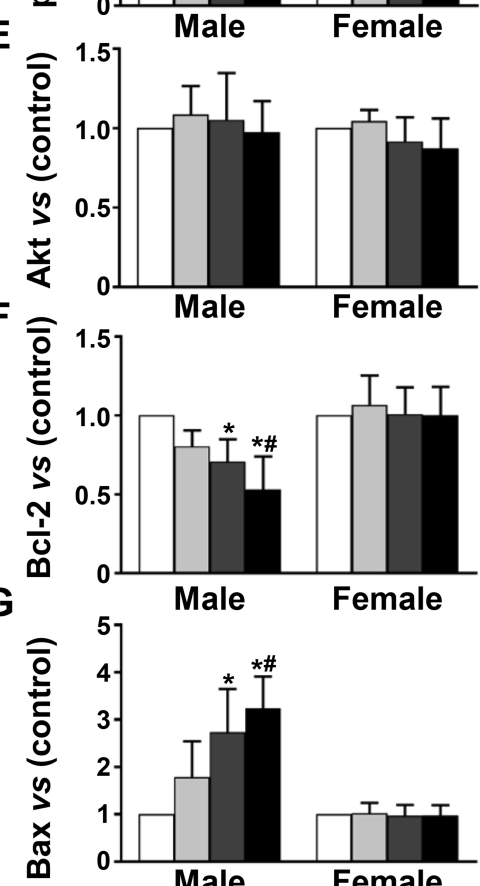

Fig. 3. Effect of maternal DEHP exposure on PI3K/AKT signaling pathway of pups at PN 14. (A) Western blot bands represent the expression level of proteins in PI3K/AKT/Bcl-2/Bax pathway at PN 14 for males and females. The bar graphs show the results of the semi-quantitative measurement of pPI3K (B), PI3K (C), p-AKT (D), AKT (E), Bcl-2 (F) and Bax (G). Each bar represents mean \pm SD. The mean expression in offspring from the 0, 30, 300, and $750 \mathrm{mg} / \mathrm{kg} / \mathrm{d}$ exposure groups is shown as a fold-change compared to the mean expression in the $0 \mathrm{mg} / \mathrm{kg} / \mathrm{d}$ group which was ascribed an arbitrary value of 1 . With each time point, ${ }^{*} \mathrm{p}<0.05 \mathrm{vs}$ control, ${ }^{*} \mathrm{p}<0.05 \mathrm{vs} 30 \mathrm{mg} / \mathrm{kg} / \mathrm{d}$ contamination group $(\mathrm{n}=6)$.

of Bax from 300 and $750 \mathrm{mg} / \mathrm{kg} / \mathrm{d}$ exposure groups was elevated (Fig. 2G, Male: $\mathrm{p}<0.05$; Fig. 3G, Male: $\mathrm{p}<0.05$ ). In addition, for female pups, no evident differences were found in the expression of p-PI3K (Fig. 2B, Female; Fig. 3B, Female), p-AKT (Fig. 2D, Female; Fig. 3D, Female), Bcl-2 (Fig. 2F, Female; Fig. 3F Female) and Bax (Fig. 2G, Female; Fig. 3G Female) at PN 7 and PN 14. Our results indicated that DEHP exposure during pregnancy and latency inhibited the PI3K/AKT signaling pathway of male offspring.

\section{Effects of MEHP on cell viability of primary cerebellar granule cell}

Cultured CGCs were identified by $\beta$-III tubulin, an appropriate marker for CGCs, which is located in the cytoplasm and axons [54]. CGCs are stained with red fluorescence in the cytoplasm and axons. Their purity was calculated by the ratio of the number of CGCs to the total number of cells. Three batches of cells and five fields per batch were selected to obtain this average. We found that the purity of primary cultured CGCs was about $95 \%$ and cells were used in subsequent experiments. CGCs cells were treated with MEHP at the indicated concentrations for $12 \mathrm{~h}, 24 \mathrm{~h}$ and 48 $\mathrm{h}$, and cell viability was measured by CCK- 8 assay. As shown in Fig. 4B, cell viability decreased with an increase in MEHP dose and exposure time. The results showed that $25 \mu \mathrm{M}$ MEHP did not noticeably affect the cell viability of CGCs after 12 and $24 \mathrm{~h}$ exposure, but decreased it after $48 \mathrm{~h}$ exposure. Moreover, exposure to $250 \mu \mathrm{M}$ MEHP for $24 \mathrm{~h}$ led to an approximately $20 \%$ reduction in cell viability when compared to the control (Fig. 4B, $\mathrm{p}<0.05$ ). The cell viability was reduced to $50 \%$ when CGCs were exposed to $1000 \mu \mathrm{M}$ MEHP for $24 \mathrm{~h}$. Based on these results, we selected 0 , 25, 100 and $250 \mu \mathrm{M}$ as MEHP exposure concentrations and $24 \mathrm{~h}$ as the exposure time for subsequent experiments to eliminate the interference of DEHP-induced cell death. 
A

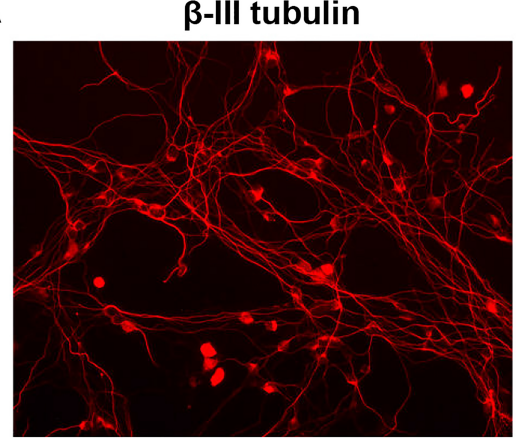

DAPI

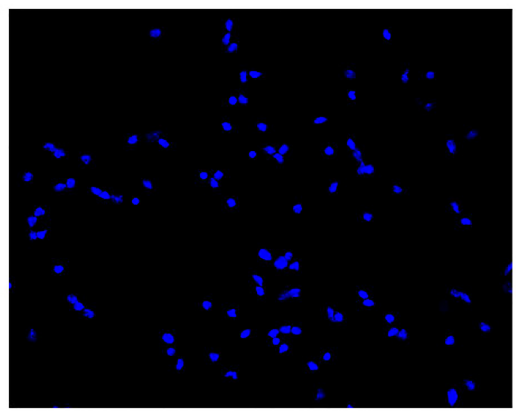

Merge

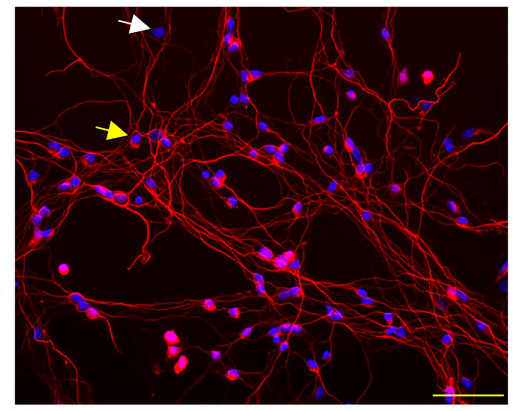

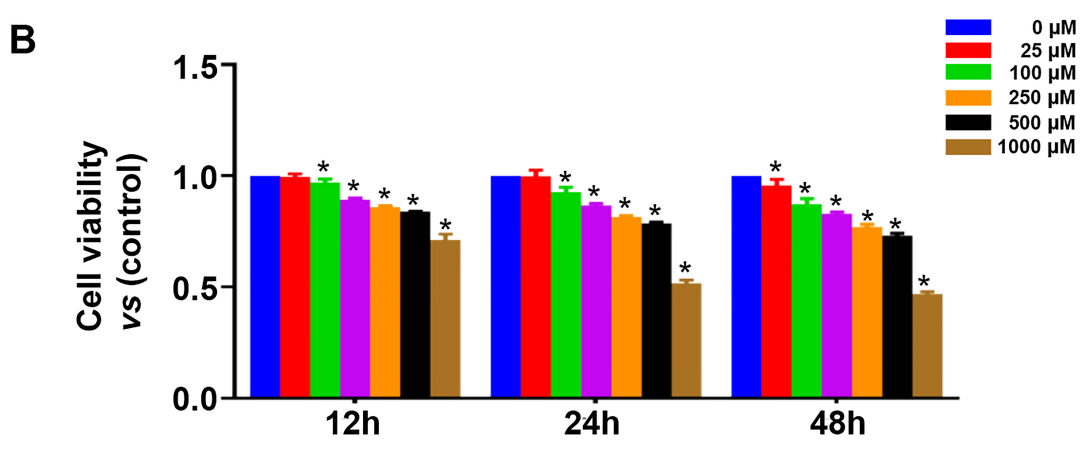

Fig. 4. Effects of MEHP on cell viability of primary CGCs. (A) Representative photomicrographs show the intact morphological structure of primary cerebellar granule cell neurons. Positive staining cells (yellow arrow) are CGCs and negative staining cells (white arrow) indicate non-CGCs, Scale bar $=100 \mu \mathrm{m}$. (B) CGCs were exposed to various concentrations of mono-(2-ethylhexyl) phthalate (MEHP; $0 \sim 1000 \mu \mathrm{M}$ ) for $12 \mathrm{~h}, 24 \mathrm{~h}$ and $48 \mathrm{~h}$, and cell viability was measured by CCK- 8 kit. Data are expressed as the mean \pm SD for three independent experiments. Each assay was performed in triplicate ${ }^{*} \mathrm{p}<0.05$ vs control.

\section{MEHP induced CGC apoptosis through inhibiting the PI3K/AKT signaling pathway in vitro}

Primary CGCs were stained by TUNEL and cleaved caspase- 3 to evaluate apoptosis induced by MEHP in vitro. The percentage of TUNEL positive cells gradually increased in CGCs as the MEHP exposure concentration increased (Fig. 5B, p<0.05). We also found that the percentage of cleaved caspase- 3 positive cells significantly increased in MEHP treatment groups in comparison with the control (Fig. 5D, p<0.05). Furthermore, the protein expression of cleaved caspase-3 was also upregulated in the three MEHP exposure groups when compared with the control (Fig. 5G, p<0.05), while the level of total caspase-3 was downregulated (Fig. 5F, $\mathrm{p}<0.05$ ).

The PI3K/AKT signaling pathway was also measured after cultured CGCs were exposed to MEHP. The results showed that $\mathrm{p}$ PI3K (Fig. 6B, p<0.05), p-AKT (Fig. 6D, p<0.05) and Bcl-2 (Fig. $6 \mathrm{~F}, \mathrm{p}<0.05)$ protein expression in MEHP exposure groups was significantly decreased when compared with the control, while the protein level of Bax (Fig. 6G, p<0.05) increased as the MEHP exposure concentration became elevated. In addition, there was no marked difference in total PI3K and AKT protein levels of the four independent groups (Fig. 6C, 6E). These results indicate that MEHP promoted CGC apoptosis via the PI3K/AKT signaling pathway in vitro.

\section{IGF1 protects CGCs from apoptosis induced by MEHP via} the PI3K/AKT pathway, while LY294002 aggravated apoptosis

IGF1 is considered to be an activator of the PI3K/AKT signaling pathway [55]. To further observe apoptosis induced by DEHP when the PI3K/AKT signaling pathway was activated, CGCs were pretreated with IGF1 (30, 50 and $100 \mathrm{ng} / \mathrm{ml})$ for $2 \mathrm{~h}$, and then treated with $250 \mu \mathrm{M}$ MEHP for $24 \mathrm{~h}$. Compared with the control group, the protein expression of Bax (Fig. 7G, p<0.05) and cleaved caspase-3 (Fig. 7I, p<0.05) increased in the MEHP only treatment group when compared with the control, while the levels of $\mathrm{p}-\mathrm{PI} 3 \mathrm{~K}$ (Fig. 7B, p<0.05), p-Akt (Fig. 7D, p<0.05), Bcl-2 (Fig. 7F, p <0.05) and total caspase 3 (Fig. $7 \mathrm{H}, \mathrm{p}<0.05$ ) proteins decreased. In addition, combined treatment with IGF1 led to the recovery of levels of $\mathrm{p}$-PI3K, $\mathrm{p}$-AKT and $\mathrm{Bcl}-2$ proteins, but decreased the expres- 


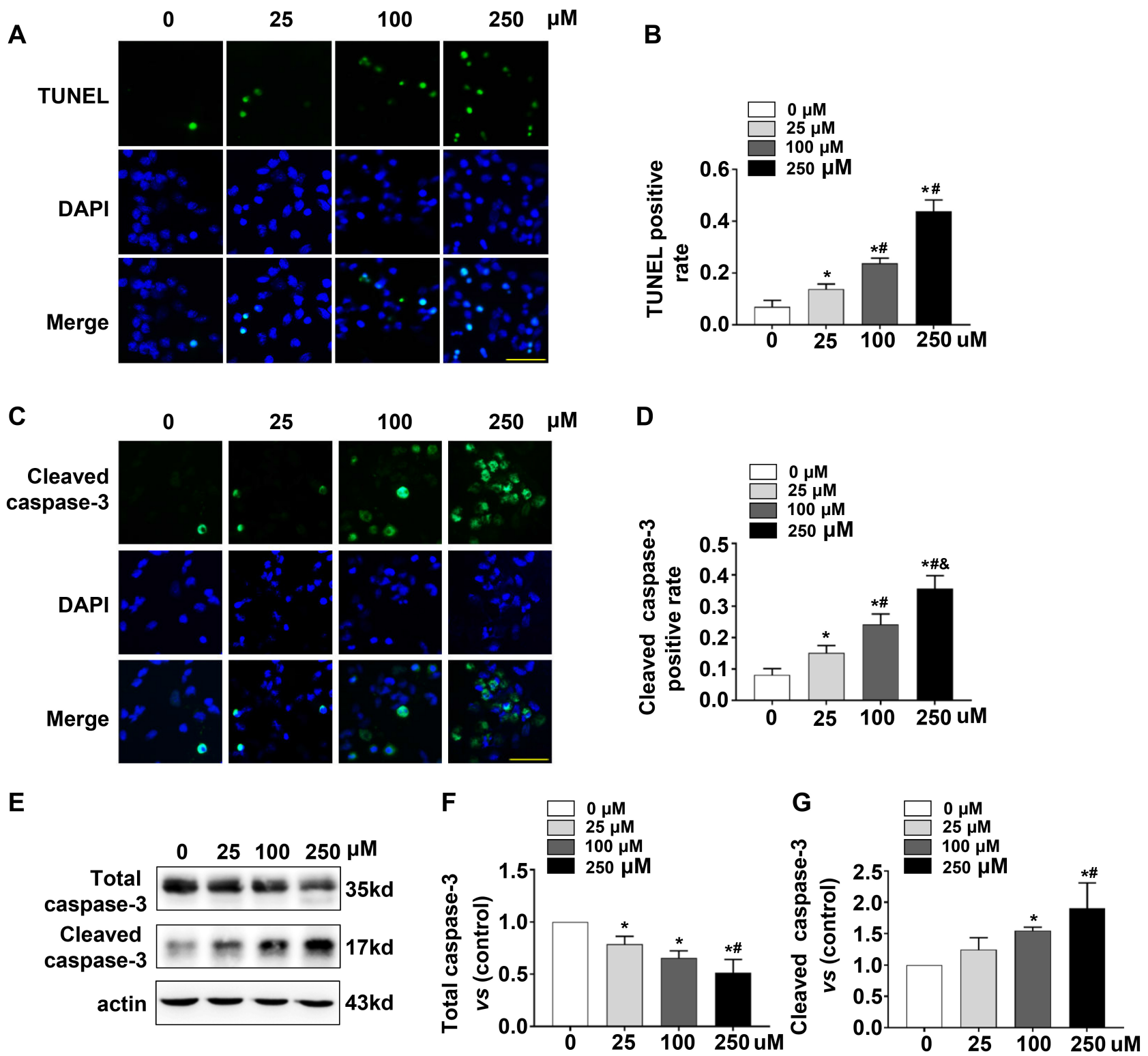

Fig. 5. MEHP induces CGC apoptosis in vitro. Cultured cerebellar granule cells (CGCs) were treated with 25, 100 and $250 \mu \mathrm{M}$ MEHP for 24 h. (A) Representative photomicrographs show the percentage of TUNEL positive CGCs in the four different exposure groups. (B) Corresponding bar graph shows TUNEL positive rate of CGCs in the four groups. (C) Representative photomicrographs show the percentage of CGCs with cleaved caspase-3 positive cells in the four groups. (D) The bar graph shows the percentage of CGCs with cleaved caspase-3 in the four exposure groups. (E) Western blot showing the expression of cleaved caspase-3 after MEHP exposure in vitro (F) Semi-quantitative measurements of cleaved caspase-3 for the four groups. (G) Semi-quantitative measurements of caspase- 3 for the four groups. ${ }^{*} \mathrm{p}<0.05$ vs control, ${ }^{*} \mathrm{p}<0.05$ vs $25 \mu \mathrm{M}$ MEHP exposure group, \& $\mathrm{p}<0.05$ vs 100 $\mu \mathrm{M}$ MEHP exposure group. Scale bar= $25 \mu \mathrm{M}$. The scale bar is the same for all images in the figure.

sion of cleaved caspase- 3 and Bax when compared to MEHP only treatment. Moreover, there was no obvious difference in the expression of these proteins between the IGF1 alone treatment and the control.

Furthermore, a TUNEL assay was performed to evaluate apoptosis after IGF1 treatment. We found that the number of cells that were TUNEL positive was reduced upon pretreatment with 100 ng/ml IGF1 in comparison with the MEHP only treatment group, and there was no evident difference between the control and IGF1 only treatment groups (Fig. $8 \mathrm{~B}, \mathrm{p}<0.05$ ). Therefore, IGF1 protects CGCs from apoptosis induced by MEHP via the PI3K/AKT pathway.

In addition, to confirm that IGF1 could rescue the inhibitory effect of DHEP on CGC cell death via partially affecting PI-3K/ 


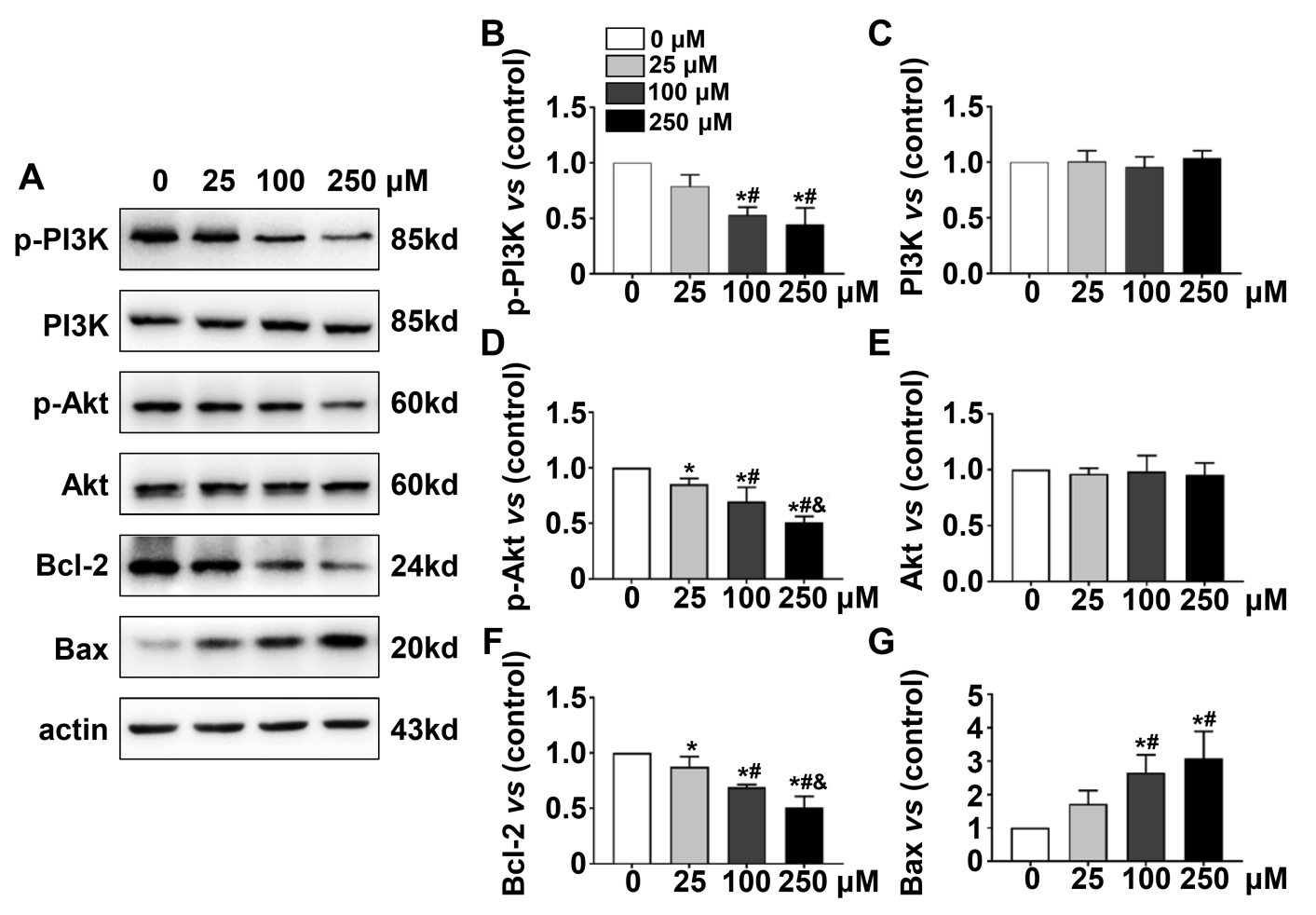

Fig. 6. MEHP disturbed the PI3K/AKT signaling pathway of CGCs in vitro. (A) Western blot bands represent the expression level of proteins in the $\mathrm{PI} 3 \mathrm{~K} / \mathrm{AKT} / \mathrm{Bcl} 2$ /Bax pathway in the four MEHP exposure $(0,25,100$ and $250 \mu \mathrm{M})$ groups of primary CGCs. The corresponding bar graphs show the results of the semi-quantitative measurement of p-PI3K (B), PI3K (C), p-AKT (D), AKT (E), Bcl-2 (F) and Bax (G). Each bar represents the mean \pm SD. Mean expression in CGCs from each MEHP exposure group is shown as a fold-change compared to the mean expression in the control group that has been ascribed an arbitrary value of 1 . With each time point, ${ }^{*} \mathrm{p}<0.05$ vs control, ${ }^{*} \mathrm{p}<0.05$ vs $250 \mu \mathrm{M}$ MEHP exposure group, \& $\mathrm{p}<0.05$ vs $100 \mu \mathrm{M}$ MEHP exposure group $(n=4)$.

AKT pathway, the PI3K/AKT signaling pathway in four groups were measured, including the control group and the experiment groups with LY294002 (chemical inhibitor of PI-3K), MEHP, and LY294002 plus MEHP. We found that DEHP had a similar effect to that of LY294002 in that it inhibited the PI3K/AKT signaling pathway (Fig. 9B, $\mathrm{p}<0.05$; Fig. 9C, $\mathrm{p}<0.05$; Fig. 9E, $\mathrm{p}<0.05$; Fig. 9F, $\mathrm{p}<0.05$; Fig. $9 \mathrm{G}, \mathrm{p}<0.05$; Fig. $9 \mathrm{H}, \mathrm{p}<0.05)$ and increased the TUNEL positive rate in CGCs (Fig. 10B, p<0.05). Moreover, the inhibition effect is more obvious when applying both MEHP and LY294002.

\section{DISCUSSION}

DEHP is one of the most widespread endocrine-disrupting chemicals in the environment $[56,57]$. DEHP and its primary metabolite, MEHP, have also been found in human tissues such as blood, urine, breast milk and amniotic fluid $[58,59]$. An increasing number of studies has shown that exposure to DEHP during pregnancy and lactation is associated with cerebellar-related neurobehavioral disorders [60-63]. However, the direct effects of DEHP on the cerebellum and any related mechanisms have not been well studied. Therefore, in this study, we established an animal model of DEHP exposure and cultured primary CGCs exposed to MEHP to observe the effects on apoptosis of CGCs and the underlying mechanisms involved.

Neuronal apoptosis and survival are closely controlled processes that regulate cell fate and homeostasis during central nervous system development [64]. In the process of apoptosis, the activation of the caspase family plays a key role. Of these, caspase- 3 is in a pivotal position. Upon activation, caspase- 3 is cleaved to producing an active subunit of cleaved caspase-3, which can further activate nucleic acid endonuclease, break down DNA fragments and eventually induce apoptosis [65]. In this study, it was found that TUNEL positive cells in the internal granular layer of $300 \mathrm{mg} / \mathrm{kg} /$ $\mathrm{d}$ and $750 \mathrm{mg} / \mathrm{kg} / \mathrm{d}$ exposure groups were increased when compared with the control group in male offspring at PN 7 and PN 14. Moreover, cleaved caspase- 3 is also elevated in comparison with the control, while total caspase- 3 is decreased. These results demonstrated that maternal exposure to DEHP could induce CGC apoptosis in male offspring, and the increased cleaved caspase- 3 

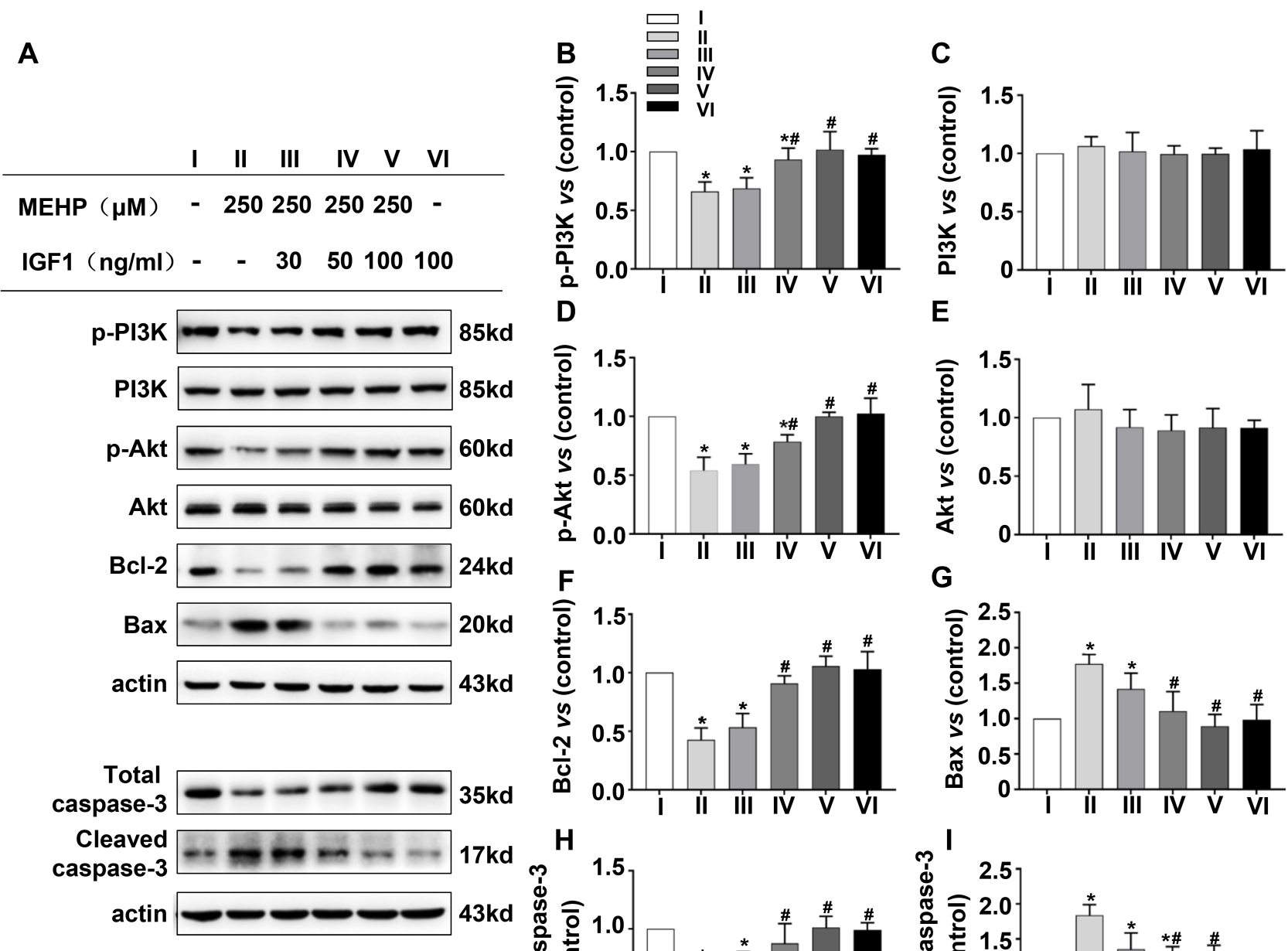

G $\mathrm{H}$
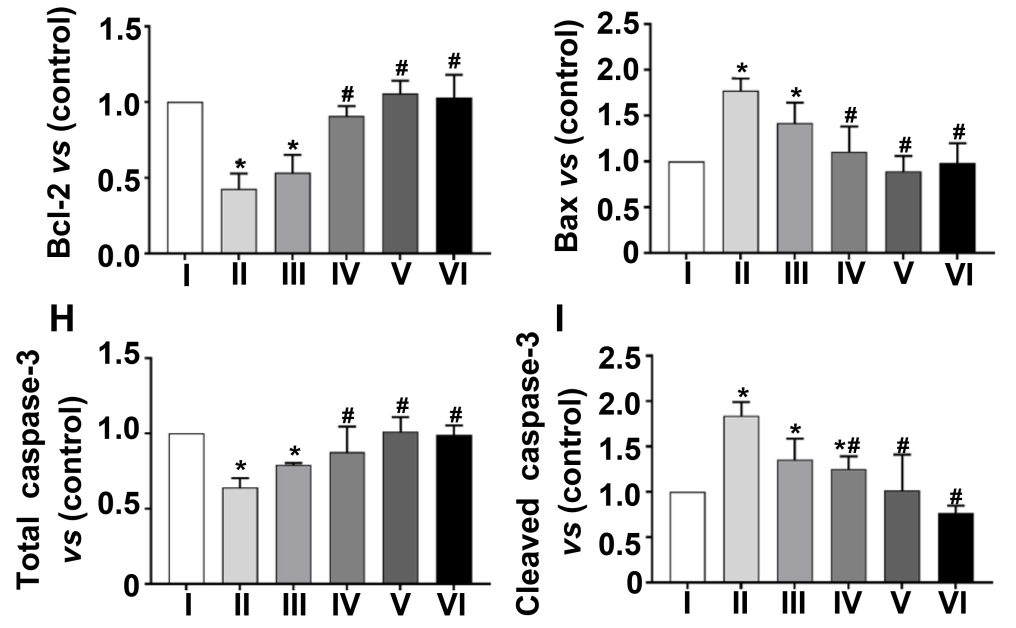

Fig. 7. IGF1 protects CGCs from apoptosis induced by MEHP by activating the PI3K/AKT pathway. CGCs were pre-treated with 30,50 and 100 ng/ $\mathrm{mL}$ of insulin-like growth factor (IGF) 1, an activator of the PI3K/AKT, signaling pathway, for $2 \mathrm{~h}$ followed by treatment with $250 \mathrm{MEHP}$ for $24 \mathrm{~h}$. (A) Western blot bands represent the expression of proteins in the PI3K/AKT/Bcl-2/Bax pathway. (B I) Each column represents the mean \pm SD. The mean expression in CGCs from each group is shown as a fold-change compared to the mean expression in the control group which was ascribed an arbitrary value of 1 . With each time point, ${ }^{*} \mathrm{p}<0.05$ vs control, ${ }^{*} \mathrm{p}<0.05$ vs MEHP only treatment group $(\mathrm{n}=4)$.

induced by DEHP might attributed to the increased proteolysis of pro-caspase-3. Similarly, another environmental endocrine disruptor significantly increased apoptotic cells in the brain [66]. To further verify whether DEHP played a role in promoting apoptosis, we cultured primary CGCs and exposed them to MEHP. MEHP is the main metabolite of DEHP in vivo, and is considered to be the primary substance that plays a role in toxicity $[67,68]$. We found that the number of cells that were TUNEL positive as well as cleaved caspase- 3 expression significantly increased with increasing MEHP concentration while the total caspase 3 level decreased. Previous studies have also shown that MEHP exposure induced caspase-3 dependent apoptosis in neuronal cells [69, 70]. These results indicated that DEHP induced CGC apoptosis.

The PI3K/AKT signaling pathway plays a crucial role in neuronal cell survival [71-73]. Activation of PI3K can phosphorylate and activate AKT by binding to its $\mathrm{PH}$ region of it, causing the translocation of AKT to the inner surface of the cell membrane [74-76]. Phosphorylated AKT (p-AKT) can further activate downstream signals, such as Bcl-2 and Bax, which participate in growth, development, differentiation and cell survival [77]. Bcl-2 promotes cell survival by blocking cell apoptosis, while Bax, in contrast to $\mathrm{Bcl}-2$, induces cell apoptosis $[78,79]$. In this investigation, we 

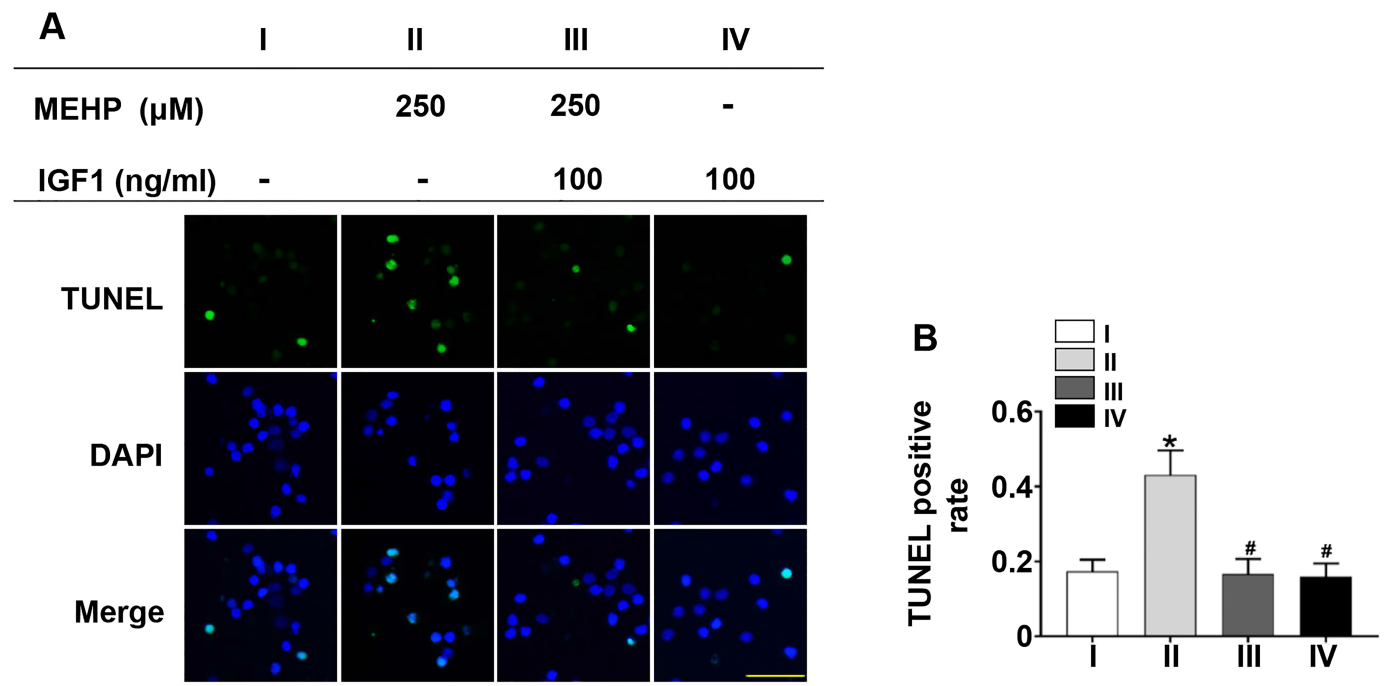

Fig. 8. IGF1 reduced apoptosis caused by MEHP exposure in vitro. CGCs were pre-treated with $100 \mathrm{ng} / \mathrm{mL}$ IGF1 for $2 \mathrm{~h}$, and then treated with $250 \mu \mathrm{M}$ MEHP for 24h. (A) Representative photomicrographs show TUNEL positive cells in the four indicated exposure groups. (B) The corresponding graph shows percentage of TUNEL positive cells in the four groups. Scale bar $=25 \mu \mathrm{m},{ }^{*} \mathrm{p}<0.05$ vs control, ${ }^{*} \mathrm{p}<0.05 \mathrm{vs}$ MEHP only treatment ( $\mathrm{n}=4$ ).
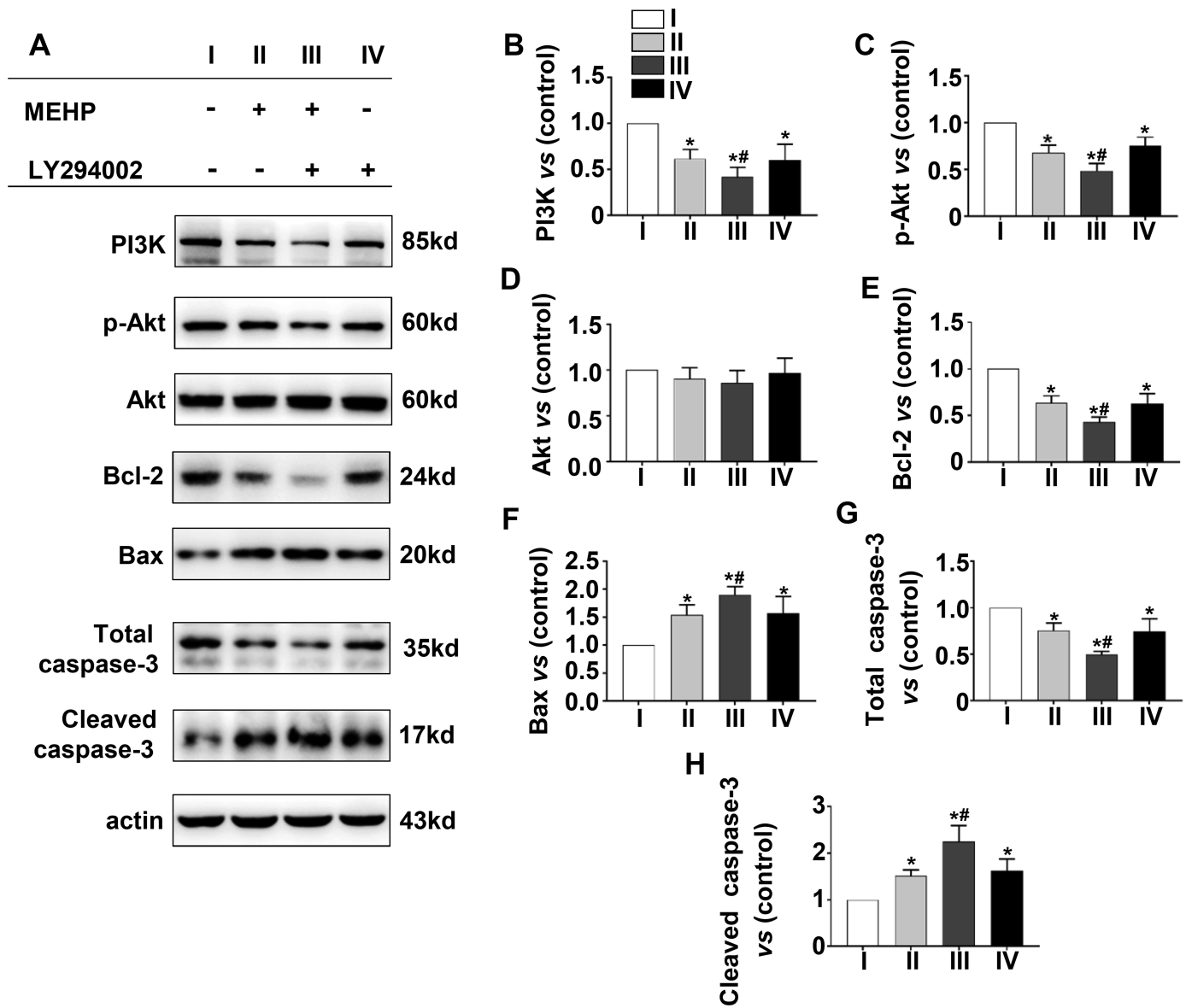

Fig. 9. LY294002 aggravated the suppression of PI3K/AKT signaling pathway induced by MEHP. CGCs were pre-treated with $5 \mu \mathrm{M}$ of LY294002, an inhibitor of PI-3K/AKT pathway, for $2 \mathrm{~h}$ followed by treatment with $250 \mathrm{MEHP}$ for $24 \mathrm{~h}$. The corresponding graphs the semi-quantitative measurement of PI3K (B), p-AKT (C), AKT (D), Bcl-2 (E), Bax (F), total caspase-3 (G) and cleaved caspase-3 (H). Each column represents the mean \pm SD. Mean expression in CGCs from each MEHP exposure group is shown as a fold-change compared to the mean expression in the control group, which was ascribed an arbitrary value of 1 . With each time point, ${ }^{*} \mathrm{p}<0.05$ vs control, ${ }^{*} \mathrm{p}<0.05 \mathrm{vs} 250 \mu \mathrm{M}$ MEHP exposure group $(\mathrm{n}=4)$. 


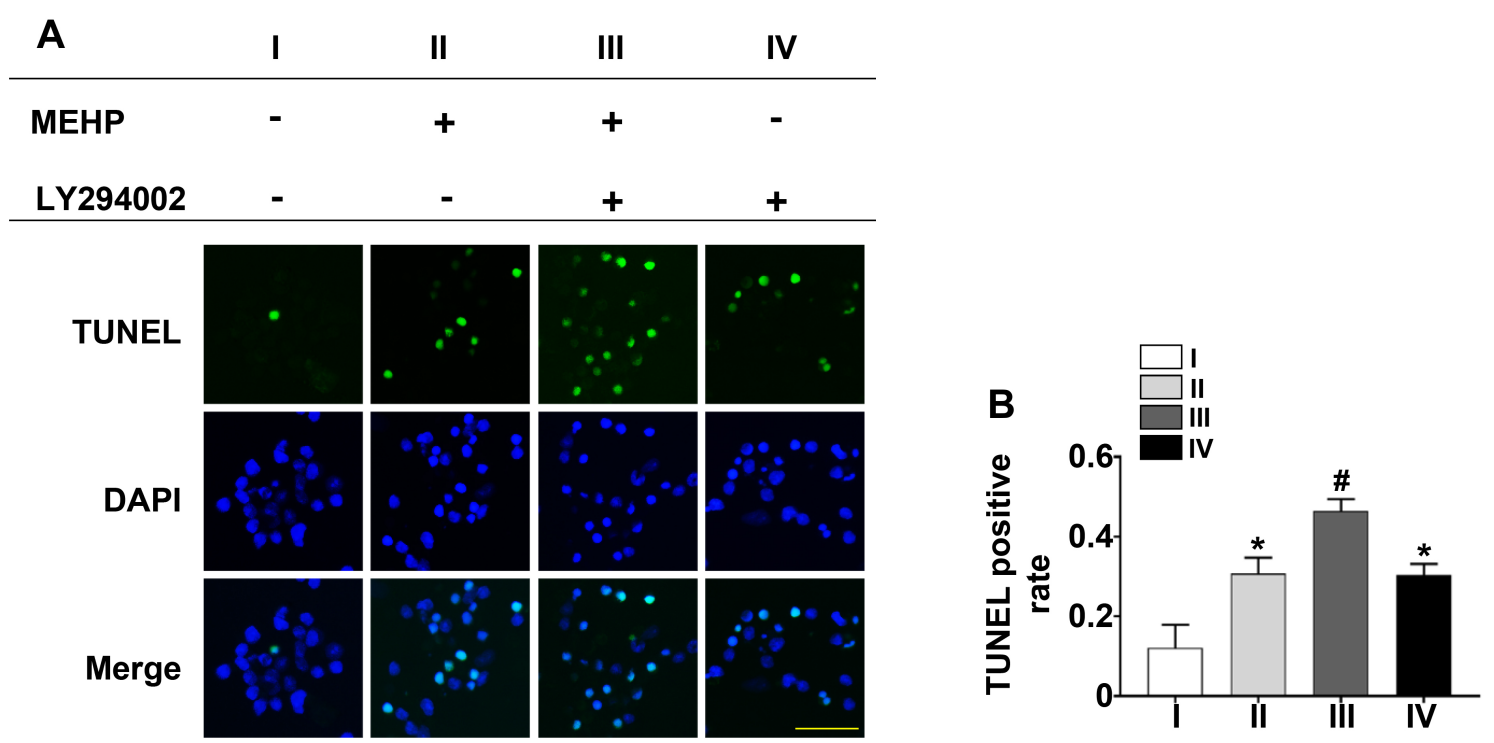

Fig. 10. LY294002 exacerbated apoptosis caused by MEHP exposure in vitro. (A) Representative photomicrographs show TUNEL positive cells in the four indicated exposure groups. (B) The corresponding graph shows percentage of TUNEL positive cells in the four groups. Scale bar $=25 \mu \mathrm{m}{ }^{*} \mathrm{p}<0.05 \mathrm{vs}$ control, ${ }^{*} \mathrm{p}<0.05$ vs MEHP only treatment $(\mathrm{n}=4)$.

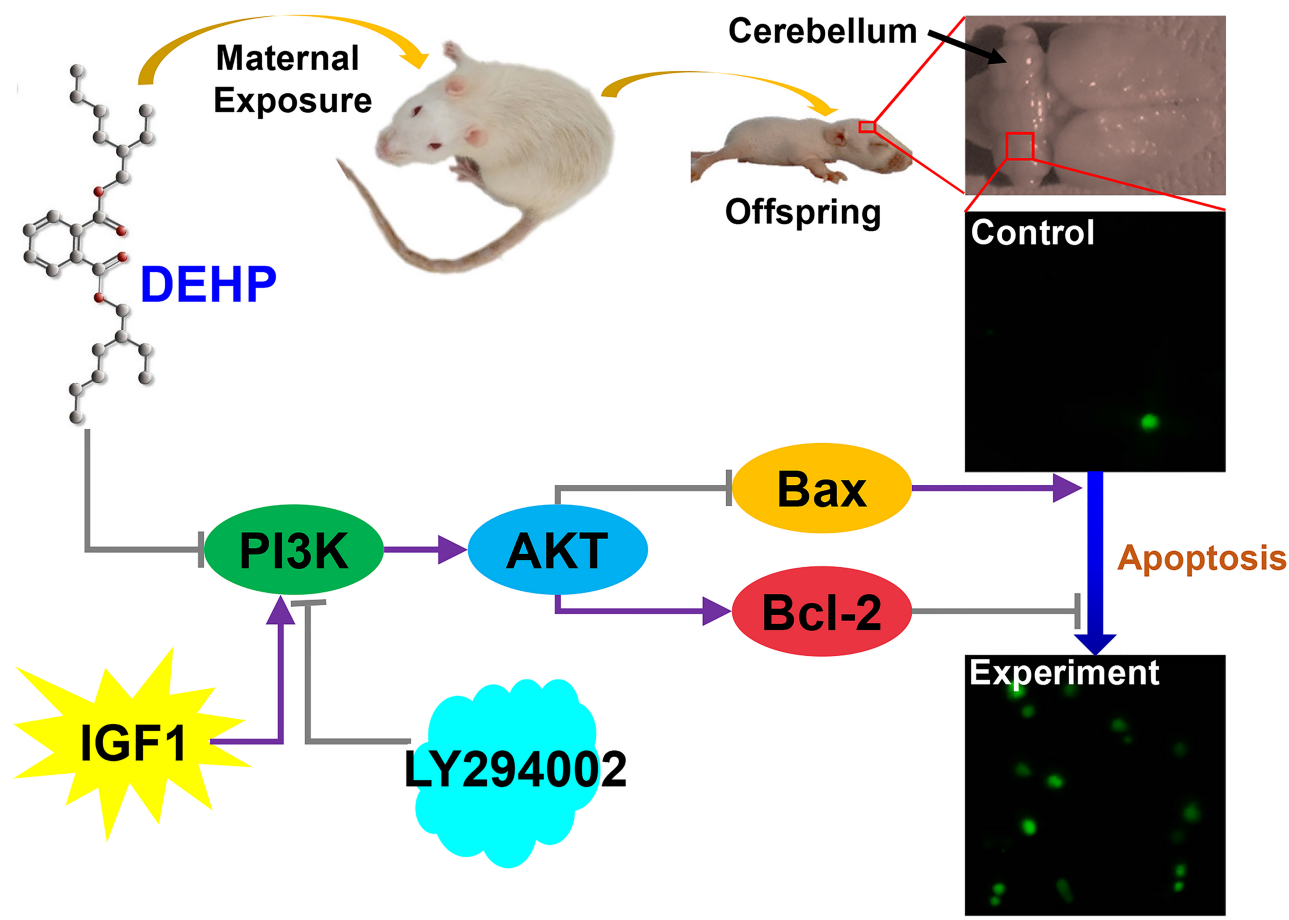

Fig. 11. Di-(2-ethylhexyl) phthalate (DEHP) induce apoptosis of cerebellar granule cells (CGCs). The apoptosis induced by DEHP is associated with inhibition of the PI3K/AKT signaling pathway. Insulin-like growth factor (IGF) 1 may partially protect CGCs from apoptosis and LY294002 aggravated the apoptosis induced by DEHP.

found that $\mathrm{p}-\mathrm{PI} 3 \mathrm{~K}, \mathrm{p}-\mathrm{AKT}, \mathrm{Bcl}-2$ and total caspase-3 expression decreased in male offspring after maternal exposure to $300 \mathrm{mg} /$ $\mathrm{kg} / \mathrm{d}$ and $750 \mathrm{mg} / \mathrm{kg} / \mathrm{d}$ DEHP, while Bax and cleaved caspase 3 expression increased. These results indicated that PI3K/AKT may be involved in the CGC apoptosis induced by DEHP. Meanwhile, the PI3K/AKT signaling pathway was measured in primary CGCs 
after exposure to MEHP, showing that the signaling pathway was also inhibited. In line with these results, other studies have shown that the PI3K/AKT pathway plays an important role in inhibiting neuronal cell apoptosis and increasing cell survival [80-82].

Various neurotrophic factors inhibit apoptosis and play a protective role in neurodevelopment by activating the PI3K/AKT signaling pathway [83-85]. As a neurotrophic factor, IGF1 can regulate cell growth and differentiation, and protect neurons from death induced by many stimuli [86]. IGF1 can activate PI3K by binding to insulin-like growth factor receptor (IGF1R) on the cell membrane, which is capable of phosphorylating downstream AKT and then inducing cascade changes of downstream substrates [87-89]. IGF1 can prevent apoptosis via the PI3K/AKT signaling pathway $[90,91]$. In order to demonstrate whether apoptosis decreased when the PI3K/AKT signaling pathway is activated, exogenous IGF1 was added to CGCs in vitro and the apoptotic level and PI3K/AKT signaling pathway then measured. We found that IGF1 reduced apoptosis in CGCs caused by MEHP, as seen in the significantly decreased number of TUNEL positive cell and reduced cleaved caspase 3 protein expression. Furthermore, the protective effect of IGF1 on CGCs was by activating the PI3K/AKT signaling pathway. Meanwhile, LY294002 aggravated apoptosis via inhibiting the signaling pathway. Taken together, these results indicated that the activation of the PI3K/AKT signaling pathway may partially rescue increased apoptosis in CGCs exposed to MEHP.

Our results showed an interesting phenomenon in that male offspring seemed to be more susceptible to DEHP exposure than female offspring. We speculated that the vulnerability of male rats to DEHP exposure may involve decreased estrogen levels through the suppression of aromatase activity in the male brain according to previous reports $[92,93]$. Our previous work also demonstrated that aromatase expression and the estrogen level in the 300 and $750 \mathrm{mg} / \mathrm{kg} / \mathrm{d}$ DEHP exposure groups significantly decreased when compared to the controls for male offspring, but did not have an evident effect on females [94]. Aromatase activity is the key enzyme in the transformation of peripheral circulating androgens to estrogens, which is the primary source of this hormone in the male brain [95], and estrogen plays an important role in CGC development [96]. Therefore, it has been speculated that DEHP affects cerebellar development by interfering with the synthesis of estrogen, making male cubs more susceptible to DEHP. Similarly, epidemiological studies have found that some neurological damage is more pronounced in men [97-99].

In summary, DEHP and its metabolite MEHP induced apoptosis of CGCs. The apoptosis induced by DEHP was associated with the inhibition of the PI3K/AKT signaling pathway. Furthermore, IGF1 may partially protect CGCs from apoptosis and LY294002 can aggravate it (Fig. 11). These findings indicate that DEHP exposure induced apoptosis in CGCs via the PI3K/AKT signaling pathway. Understanding the pathological effect of DEHP exposure may bring in treatments for DEHP overexposure. Also, a line on future research directions would be useful.

\section{ACKNOWLEDGEMENTS}

This work was supported by the National Natural Science Foundation of China (grant number 81472943) and the Program for Liaoning Excellent Talents in University (grant number LJQ2015113), and Program for Liaoning Innovative Research Team in University (grant number LT2015028).

\section{REFERENCES}

1. Zhang T, Shen W, De Felici M, Zhang XF (2016) Di(2-ethylhexyl)phthalate: adverse effects on folliculogenesis that cannot be neglected. Environ Mol Mutagen 57:579-588.

2. García Ibarra V, Rodríguez Bernaldo de Quirós A, Paseiro Losada P, Sendón R (2018) Identification of intentionally and non-intentionally added substances in plastic packaging materials and their migration into food products. Anal Bioanal Chem 410:3789-3803.

3. Bernard L, Décaudin B, Lecoeur M, Richard D, Bourdeaux D, Cueff R, Sautou V; Armed Study Group (2014) Analytical methods for the determination of DEHP plasticizer alternatives present in medical devices: a review. Talanta 129:39-54.

4. Braun JM, Sathyanarayana S, Hauser R (2013) Phthalate exposure and children's health. Curr Opin Pediatr 25:247-254.

5. Erythropel HC, Maric M, Nicell JA, Leask RL, Yargeau V (2014) Leaching of the plasticizer di(2-ethylhexyl)phthalate (DEHP) from plastic containers and the question of human exposure. Appl Microbiol Biotechnol 98:9967-9981.

6. Junaid M, Jia PP, Tang YM, Xiong WX, Huang HY, Strauss PR, Li WG, Pei DS (2018) Mechanistic toxicity of DEHP at environmentally relevant concentrations (ERCs) and ecological risk assessment in the Three Gorges Reservoir Area, China. Environ Pollut 242:1939-1949.

7. Mankidy R, Wiseman S, Ma H, Giesy JP (2013) Biological impact of phthalates. Toxicol Lett 217:50-58.

8. Bakir A, O'Connor IA, Rowland SJ, Hendriks AJ, Thompson RC (2016) Relative importance of microplastics as a pathway for the transfer of hydrophobic organic chemicals to marine life. Environ Pollut 219:56-65.

9. Lee KI, Chiang CW, Lin HC, Zhao JF, Li CT, Shyue SK, Lee TS (2016) Maternal exposure to di-(2-ethylhexyl) phthalate 
exposure deregulates blood pressure, adiposity, cholesterol metabolism and social interaction in mouse offspring. Arch Toxicol 90:1211-1224.

10. Wittassek M, Angerer J (2008) Phthalates: metabolism and exposure. Int J Androl 31:131-138.

11. Shea KM; American Academy of Pediatrics Committee on Environmental Health (2003) Pediatric exposure and potential toxicity of phthalate plasticizers. Pediatrics 111:14671474.

12. Buckley JP, Palmieri RT, Matuszewski JM, Herring AH, Baird DD, Hartmann KE, Hoppin JA (2012) Consumer product exposures associated with urinary phthalate levels in pregnant women. J Expo Sci Environ Epidemiol 22:468-475.

13. Wang B, Liu F, Dong J, You M, Fu Y, Li C, Lu Y, Chen J (2018) Maternal exposure to environmental DEHP exacerbated OVA-induced asthmatic responses in rat offspring. Sci Total Environ 615:253-261.

14. Fromme H, Gruber L, Seckin E, Raab U, Zimmermann S, Kiranoglu M, Schlummer M, Schwegler U, Smolic S, Völkel W; HBMnet (2011) Phthalates and their metabolites in breast milk--results from the Bavarian Monitoring of Breast Milk (BAMBI). Environ Int 37:715-722.

15. You M, Dong J, Fu Y, Cong Z, Fu H, Wei L, Wang Y, Wang Y, Chen J (2018) Exposure to Di-(2-ethylhexyl) phthalate during perinatal period gender-specifically impairs the dendritic growth of pyramidal neurons in rat offspring. Front Neurosci 12:444.

16. Sathyanarayana S, Grady R, Barrett ES, Redmon B, Nguyen RH, Barthold JS, Bush NR, Swan SH (2016) First trimester phthalate exposure and male newborn genital anomalies. Environ Res 151:777-782.

17. Wang Y, Yang Q, Liu W, Yu M, Zhang Z, Cui X (2016) DEHP exposure in utero disturbs sex determination and is potentially linked with precocious puberty in female mice. Toxicol Appl Pharmacol 307:123-129.

18. de Cock M, de Boer MR, Lamoree M, Legler J, van de Bor M (2014) Prenatal exposure to endocrine disrupting chemicals in relation to thyroid hormone levels in infants - a Dutch prospective cohort study. Environ Health 13:106.

19. Tang C, Deng Y, Duan H, Yi Z, Li Y, Qiu D, Zhou K, Hua Y, Wang C (2018) The effect of maternal exposure to di-(2ethylhexyl)-phthalate on fetal cardiac development in mice. J Appl Toxicol 38:834-842.

20. Hatten ME, Heintz N (1995) Mechanisms of neural patterning and specification in the developing cerebellum. Annu Rev Neurosci 18:385-408.

21. Hatten ME, Roussel MF (2011) Development and cancer of the cerebellum. Trends Neurosci 34:134-142.

22. Wang SS, Kloth AD, Badura A (2014) The cerebellum, sensitive periods, and autism. Neuron 83:518-532.

23. Wagner MJ, Kim TH, Savall J, Schnitzer MJ, Luo L (2017) Cerebellar granule cells encode the expectation of reward. Nature 544:96-100.

24. Brun SN, Markant SL, Esparza LA, Garcia G, Terry D, Huang JM, Pavlyukov MS, Li XN, Grant GA, Crawford JR, Levy ML, Conway EM, Smith LH, Nakano I, Berezov A, Greene MI, Wang Q, Wechsler-Reya RJ (2015) Survivin as a therapeutic target in Sonic hedgehog-driven medulloblastoma. Oncogene 34:3770-3779.

25. Scheuer T, Sharkovska Y, Tarabykin V, Marggraf K, Brockmöller V, Bührer C, Endesfelder S, Schmitz T (2018) Neonatal hyperoxia perturbs neuronal development in the cerebellum. Mol Neurobiol 55:3901-3915.

26. Wang Y, Hersheson J, Lopez D, Hammer M, Liu Y, Lee KH, Pinto V, Seinfeld J, Wiethoff S, Sun J, Amouri R, Hentati F, Baudry N, Tran J, Singleton AB, Coutelier M, Brice A, Stevanin G, Durr A, Bi X, Houlden H, Baudry M (2016) Defects in the CAPN1 gene result in alterations in cerebellar development and cerebellar ataxia in mice and humans. Cell Reports 16:79-91.

27. Elmore S (2007) Apoptosis: a review of programmed cell death. Toxicol Pathol 35:495-516.

28. Ghavami S, Shojaei S, Yeganeh B, Ande SR, Jangamreddy JR, Mehrpour M, Christoffersson J, Chaabane W, Moghadam AR, Kashani HH, Hashemi M, Owji AA, Łos MJ (2014) Autophagy and apoptosis dysfunction in neurodegenerative disorders. Prog Neurobiol 112:24-49.

29. Zhang L, Fang Y, Cheng X, Lian YJ, Xu HL (2018) Silencing of long noncoding RNA SOX21-AS1 relieves neuronal oxidative stress injury in mice with Alzheimer's disease by upregulating FZD3/5 via the Wnt signaling pathway. Mol Neurobiol (in press).

30. Vila M, Przedborski S (2003) Targeting programmed cell death in neurodegenerative diseases. Nat Rev Neurosci 4:365375.

31. Charriaut-Marlangue C, Remolleau S, Aggoun-Zouaoui D, Ben-Ari Y (1998) Apoptosis and programmed cell death: a role in cerebral ischemia. Biomed Pharmacother 52:264-269.

32. Fu Z, Yang J, Wei Y, Li J (2016) Effects of piceatannol and pterostilbene against $\beta$-amyloid-induced apoptosis on the $\mathrm{PI} 3 \mathrm{~K} / \mathrm{AKT} / \mathrm{Bad}$ signaling pathway in PC12 cells. Food Funct 7:1014-1023.

33. Qi D, Ouyang C, Wang Y, Zhang S, Ma X, Song Y, Yu H, Tang J, Fu W, Sheng L, Yang L, Wang M, Zhang W, Miao L, Li T, Huang 
X, Dong H (2014) HO-1 attenuates hippocampal neurons injury via the activation of BDNF-TrkB-PI3K/AKT signaling pathway in stroke. Brain Res 1577:69-76.

34. Kim EH, Suresh M (2013) Role of PI3K/AKT signaling in memory CD8 T cell differentiation. Front Immunol 4:20.

35. Martini M, De Santis MC, Braccini L, Gulluni F, Hirsch E (2014) PI3K/AKT signaling pathway and cancer: an updated review. Ann Med 46:372-383.

36. Yang H, Lee MH, Park I, Jeon H, Choi J, Seo S, Kim SW, Koh GY, Park KS, Lee DH (2017) HSP90 inhibitor (NVP-AUY922) enhances the anti-cancer effect of BCL-2 inhibitor (ABT737) in small cell lung cancer expressing BCL-2. Cancer Lett 411:19-26.

37. Hers I, Vincent EE, Tavaré JM (2011) AKT signalling in health and disease. Cell Signal 23:1515-1527.

38. Russo A, Cardile V, Graziano A, Avola R, Bruno M, Rigano D (2018) Involvement of Bax and Bcl-2 in induction of apoptosis by essential oils of three Lebanese Salvia species in human prostate cancer cells. Int J Mol Sci 19:292.

39. Law NC, White MF, Hunzicker-Dunn ME (2016) G proteincoupled receptors (GPCRs) that signal via protein kinase A (PKA) cross-talk at insulin receptor substrate 1 (IRS1) to activate the phosphatidylinositol 3-kinase (PI3K)/AKT pathway. J Biol Chem 291:27160-27169.

40. Barakat R, Lin PC, Park CJ, Best-Popescu C, Bakry HH, Abosalem ME, Abdelaleem NM, Flaws JA, Ko C (2018) Prenatal exposure to DEHP induces neuronal degeneration and neurobehavioral abnormalities in adult male mice. Toxicol Sci 164:439-452.

41. Smith CA, Macdonald A, Holahan MR (2011) Acute postnatal exposure to di(2-ethylhexyl) phthalate adversely impacts hippocampal development in the male rat. Neuroscience 193:100-108.

42. Park S, Lee JM, Kim JW, Cheong JH, Yun HJ, Hong YC, Kim Y, Han DH, Yoo HJ, Shin MS, Cho SC, Kim BN (2015) Association between phthalates and externalizing behaviors and cortical thickness in children with attention deficit hyperactivity disorder. Psychol Med 45:1601-1612.

43. Komada M, Gendai Y, Kagawa N, Nagao T (2016) Prenatal exposure to di(2-ethylhexyl) phthalate impairs development of the mouse neocortex. Toxicol Lett 259:69-79.

44. Win-Shwe TT, Yanagisawa R, Koike E, Nitta H, Takano H (2013) Expression levels of neuroimmune biomarkers in hypothalamus of allergic mice after phthalate exposure. J Appl Toxicol 33:1070-1078.

45. Carbone S, Szwarcfarb B, Ponzo O, Reynoso R, Cardoso N, Deguiz L, Moguilevsky JA, Scacchi P (2010) Impact of gesta- tional and lactational phthalate exposure on hypothalamic content of amino acid neurotransmitters and FSH secretion in peripubertal male rats. Neurotoxicology 31:747-751.

46. Hirosawa N, Yano K, Suzuki Y, Sakamoto Y (2006) Endocrine disrupting effect of di-(2-ethylhexyl)phthalate on female rats and proteome analyses of their pituitaries. Proteomics 6:958971.

47. Moore RW, Rudy TA, Lin TM, Ko K, Peterson RE (2001) Abnormalities of sexual development in male rats with in utero and lactational exposure to the antiandrogenic plasticizer di(2-ethylhexyl) phthalate. Environ Health Perspect 109:229237.

48. Sato M, Suzuki K, Nakanishi S (2001) NMDA receptor stimulation and brain-derived neurotrophic factor upregulate homer 1a mRNA via the mitogen-activated protein kinase cascade in cultured cerebellar granule cells. J Neurosci 21:3797-3805.

49. Krämer D, Minichiello L (2010) Cell culture of primary cerebellar granule cells. Methods Mol Biol 633:233-239.

50. Qiu W, Carson-Walter EB, Liu H, Epperly M, Greenberger JS, Zambetti GP, Zhang L, Yu J (2008) PUMA regulates intestinal progenitor cell radiosensitivity and gastrointestinal syndrome. Cell Stem Cell 2:576-583.

51. Parrish AB, Freel CD, Kornbluth S (2013) Cellular mechanisms controlling caspase activation and function. Cold Spring Harb Perspect Biol 5:a008672.

52. Wolin EM (2013) PI3K/AKT/mTOR pathway inhibitors in the therapy of pancreatic neuroendocrine tumors. Cancer Lett 335:1-8.

53. Mayer IA, Arteaga CL (2016) The PI3K/AKT pathway as a target for cancer treatment. Annu Rev Med 67:11-28.

54. Collins LL, Williamson MA, Thompson BD, Dever DP, Gasiewicz TA, Opanashuk LA (2008) 2,3,7,8-Tetracholorodibenzo-p-dioxin exposure disrupts granule neuron precursor maturation in the developing mouse cerebellum. Toxicol Sci 103:125-136.

55. Suman S, Kallakury BV, Fornace AJ Jr, Datta K (2015) Protracted upregulation of leptin and IGF1 is associated with activation of PI3K/AKT and JAK2 pathway in mouse intestine after ionizing radiation exposure. Int J Biol Sci 11:274-283.

56. Zhang C, Xie M, Chen J, Zhang Y, Wei S, Ma X, Xiao L, Chen L (2018) UV-B radiation induces DEHP degradation and their combined toxicological effects on Scenedesmus acuminatus. Aquat Toxicol 203:172-178.

57. Qin X, Ma Q, Yuan J, Hu X, Tan Q, Zhang Z, Wang L, Xu X (2018) The effects of di-2-ethylhexyl phthalate on testicular ultrastructure and hormone-regulated gene expression in 
male rats. Toxicol Res (Camb) 7:408-414.

58. Quinnies KM, Doyle TJ, Kim KH, Rissman EF (2015) Transgenerational effects of di-(2-ethylhexyl) phthalate (DEHP) on stress hormones and behavior. Endocrinology 156:30773083.

59. Wojtowicz AK, Sitarz-Glownia AM, Szczesna M, Szychowski KA (2018) The action of di-(2-ethylhexyl) phthalate (DEHP) in mouse cerebral cells involves an impairment in aryl hydrocarbon receptor (AhR) signaling. Neurotox Res (in press).

60. Engel SM, Villanger GD, Nethery RC, Thomsen C, Sakhi AK, Drover SS, Hoppin JA, Zeiner P, Knudsen GP, ReichbornKjennerud T, Herring AH, Aase H (2018) Prenatal phthalates, maternal thyroid function, and risk of attention-deficit hyperactivity disorder in the norwegian mother and child cohort. Environ Health Perspect 126:057004.

61. Verstraete S, Vanhorebeek I, Covaci A, Güiza F, Malarvannan G, Jorens PG, Van den Berghe G (2016) Circulating phthalates during critical illness in children are associated with long-term attention deficit: a study of a development and a validation cohort. Intensive Care Med 42:379-392.

62. Gascon M, Valvi D, Forns J, Casas M, Martínez D, Júlvez J, Monfort N, Ventura R, Sunyer J, Vrijheid M (2015) Prenatal exposure to phthalates and neuropsychological development during childhood. Int J Hyg Environ Health 218:550-558.

63. Du ZH, Xia J, Sun XC, Li XN, Zhang C, Zhao HS, Zhu SY, Li JL (2017) A novel nuclear xenobiotic receptors (AhR/PXR/ CAR)-mediated mechanism of DEHP-induced cerebellar toxicity in quails (Coturnix japonica) via disrupting CYP enzyme system homeostasis. Environ Pollut 226:435-443.

64. Cavallaro S (2015) Cracking the code of neuronal apoptosis and survival. Cell Death Dis 6:e1963.

65. Choi BH, Kim W, Wang QC, Kim DC, Tan SN, Yong JW, Kim KT, Yoon HS (2008) Kinetin riboside preferentially induces apoptosis by modulating Bcl-2 family proteins and caspase- 3 in cancer cells. Cancer Lett 261:37-45.

66. Wang F, Fang M, Hinton DE, Chernick M, Jia S, Zhang Y, Xie L, Dong W, Dong W (2018) Increased coiling frequency linked to apoptosis in the brain and altered thyroid signaling in zebrafish embryos (Danio rerio) exposed to the PBDE metabolite 6-OH-BDE-47. Chemosphere 198:342-350.

67. Mittermeier A, Völkel W, Fromme H (2016) Kinetics of the phthalate metabolites mono-2-ethylhexyl phthalate (MEHP) and mono-n-butyl phthalate (MnBP) in male subjects after a single oral dose. Toxicol Lett 252:22-28.

68. Erkekoğlu P, Rachidi W, De Rosa V, Giray B, Favier A, Hincal F (2010) Protective effect of selenium supplementation on the genotoxicity of di(2-ethylhexyl)phthalate and mono(2- ethylhexyl)phthalate treatment in LNCaP cells. Free Radic Biol Med 49:559-566.

69. Aung KH, Win-Shwe TT, Kanaya M, Takano H, Tsukahara S (2014) Involvement of hemeoxygenase-1 in di(2-ethylhexyl) phthalate (DEHP)-induced apoptosis of Neuro-2a cells. J Toxicol Sci 39:217-229.

70. Lim CK, Kim SK, Ko DS, Cho JW, Jun JH, An SY, Han JH, Kim JH, Yoon YD (2009) Differential cytotoxic effects of mono-(2ethylhexyl) phthalate on blastomere-derived embryonic stem cells and differentiating neurons. Toxicology 264:145-154.

71. Tu L, Wang Y, Chen D, Xiang P, Shen J, Li Y, Wang S (2018) Protective Effects of notoginsenoside R1 via regulation of the PI3K-AKT-mTOR/JNK pathway in neonatal cerebral hypoxic-ischemic brain injury. Neurochem Res 43:1210-1226.

72. Srivastava P, Dhuriya YK, Kumar V, Srivastava A, Gupta R, Shukla RK, Yadav RS, Dwivedi HN, Pant AB, Khanna VK (2018) PI3K/AKT/GSK3 $\beta$ induced CREB activation ameliorates arsenic mediated alterations in NMDA receptors and associated signaling in rat hippocampus: neuroprotective role of curcumin. Neurotoxicology 67:190-205.

73. Chen J, Alberts I, Li X (2014) Dysregulation of the IGF-I/ $\mathrm{PI} 3 \mathrm{~K} / \mathrm{AKT} / \mathrm{mTOR}$ signaling pathway in autism spectrum disorders. Int J Dev Neurosci 35:35-41.

74. Zhang L, Zhou F, ten Dijke P (2013) Signaling interplay between transforming growth factor- $\beta$ receptor and PI3K/AKT pathways in cancer. Trends Biochem Sci 38:612-620.

75. Narla G, Sangodkar J, Ryder CB (2018) The impact of phosphatases on proliferative and survival signaling in cancer. Cell Mol Life Sci 75:2695-2718.

76. Chalhoub N, Zhu G, Zhu X, Baker SJ (2009) Cell type specificity of PI3K signaling in Pdk1- and Pten-deficient brains. Genes Dev 23:1619-1624.

77. Feng M, Li J, Wang J, Ma C, Jiao Y, Wang Y, Zhang J, Sun Q, Ju Y, Gao L, Zhao Y (2014) High glucose increases LPS-induced DC apoptosis through modulation of ERK1/2, AKT and Bax/ Bcl-2. BMC Gastroenterol 14:98.

78. Mei JM, Niu CS (2014) Effects of CDNF on 6-OHDAinduced apoptosis in PC12 cells via modulation of Bcl-2/Bax and caspase-3 activation. Neurol Sci 35:1275-1280.

79. Maes ME, Schlamp CL, Nickells RW (2017) BAX to basics: how the BCL2 gene family controls the death of retinal ganglion cells. Prog Retin Eye Res 57:1-25.

80. Nakanishi A, Wada Y, Kitagishi Y, Matsuda S (2014) Link between PI3K/AKT/PTEN pathway and NOX proteinin diseases. Aging Dis 5:203-211.

81. Kitagishi Y, Matsuda S (2013) Diets involved in PPAR and $\mathrm{PI} 3 \mathrm{~K} / \mathrm{AKT} / \mathrm{PTEN}$ pathway may contribute to neuroprotec- 
tion in a traumatic brain injury. Alzheimers Res Ther 5:42.

82. Vázquez de la Torre A, Junyent F, Folch J, Pelegrí C, Vilaplana J, Auladell C, Beas-Zarate C, Pallàs M, Verdaguer E, Camins A (2013) PI3 K/AKT inhibition induces apoptosis through p38 activation in neurons. Pharmacol Res 70:116-125.

83. Ding ML, Ma H, Man YG, Lv HY (2017) Protective effects of a green tea polyphenol, epigallocatechin-3-gallate, against sevoflurane-induced neuronal apoptosis involve regulation of CREB/BDNF/TrkB and PI3K/AKT/mTOR signalling pathways in neonatal mice. Can J Physiol Pharmacol 95:13961405.

84. Mnich K, Carleton LA, Kavanagh ET, Doyle KM, Samali A, Gorman AM (2014) Nerve growth factor-mediated inhibition of apoptosis post-caspase activation is due to removal of active caspase- 3 in a lysosome-dependent manner. Cell Death Dis 5:e1202.

85. Jie B, Zhang X, Wu X, Xin Y, Liu Y, Guo Y (2012) Neuregulin-1 suppresses cardiomyocyte apoptosis by activating PI3K/AKT and inhibiting mitochondrial permeability transition pore. Mol Cell Biochem 370:35-43.

86. Haramoto Y, Takahashi S, Oshima T, Onuma Y, Ito Y, Asashima M (2015) Insulin-like factor regulates neural induction through an IGF1 receptor-independent mechanism. Sci Rep 5:11603.

87. Pang Y, Zheng B, Fan LW, Rhodes PG, Cai Z (2007) IGF1 protects oligodendrocyte progenitors against TNFalphainduced damage by activation of PI3K/AKT and interruption of the mitochondrial apoptotic pathway. Glia 55:1099-1107.

88. Mani AM, Fenwick MA, Cheng Z, Sharma MK, Singh D, Wathes DC (2010) IGF1 induces up-regulation of steroidogenic and apoptotic regulatory genes via activation of phosphatidylinositol-dependent kinase/AKT in bovine granulosa cells. Reproduction 139:139-151.

89. Ikink GJ, Boer M, Bakker ER, Hilkens J (2016) IRS4 induces mammary tumorigenesis and confers resistance to HER2targeted therapy through constitutive PI3K/AKT-pathway hyperactivation. Nat Commun 7:13567.

90. Liao R, Yan F, Zeng Z, Wang H, Qiu K, Xu J, Zheng W (2018) Insulin-like growth factor-1 activates PI3K/AKT signalling to protect human retinal pigment epithelial cells from amioda- rone-induced oxidative injury. Br J Pharmacol 175:125-139.

91. Zhang M, Liu J, Li M, Zhang S, Lu Y, Liang Y, Zhao K, Li Y (2018) Insulin-like growth factor 1 /insulin-like growth factor 1 receptor signaling protects against cell apoptosis through the PI3K/AKT pathway in glioblastoma cells. Exp Ther Med 16:1477-1482.

92. Andrade AJ, Grande SW, Talsness CE, Grote K, Chahoud I (2006) A dose-response study following in utero and lactational exposure to di-(2-ethylhexyl)-phthalate (DEHP): nonmonotonic dose-response and low dose effects on rat brain aromatase activity. Toxicology 227:185-192.

93. Borch J, Metzdorff SB, Vinggaard AM, Brokken L, Dalgaard M (2006) Mechanisms underlying the anti-androgenic effects of diethylhexyl phthalate in fetal rat testis. Toxicology 223:144-155.

94. Fu Y, Dong J, You M, Cong Z, Wei L, Fu H, Wang Y, Wang Y, Chen J (2019) Maternal di-(2-ethylhexyl) phthalate exposure inhibits cerebellar granule precursor cell proliferation via down-regulating the Shh signaling pathway in male offspring. Chemosphere 215:313-322.

95. Wu MV, Manoli DS, Fraser EJ, Coats JK, Tollkuhn J, Honda S, Harada N, Shah NM (2009) Estrogen masculinizes neural pathways and sex-specific behaviors. Cell 139:61-72.

96. Cookman CJ, Belcher SM (2015) Estrogen receptor- $\beta$ upregulates IGF1R expression and activity to inhibit apoptosis and increase growth of medulloblastoma. Endocrinology 156:2395-2408.

97. Yolton K, Xu Y, Strauss D, Altaye M, Calafat AM, Khoury J (2011) Prenatal exposure to bisphenol A and phthalates and infant neurobehavior. Neurotoxicol Teratol 33:558-566.

98. Kim Y, Ha EH, Kim EJ, Park H, Ha M, Kim JH, Hong YC, Chang N, Kim BN (2011) Prenatal exposure to phthalates and infant development at 6 months: prospective Mothers and Children's Environmental Health (MOCEH) study. Environ Health Perspect 119:1495-1500.

99. Cho SC, Bhang SY, Hong YC, Shin MS, Kim BN, Kim JW, Yoo HJ, Cho IH, Kim HW (2010) Relationship between environmental phthalate exposure and the intelligence of school-age children. Environ Health Perspect 118:1027-1032. 